

\title{
WHITE PAPER
}

\section{Livestock Manure Treatment Technology of the Netherlands and Situation of China}

\author{
J. Yan $^{1}$ \\ F.E. de Buisonjé \\ R.W. Melse ${ }^{2}$ \\ ${ }^{1}$ Wageningen UR China Office \\ 2 Wageningen Livestock Research
}

This research was conducted by Wageningen Livestock Research, commissioned and funded by the Netherlands Ministry of Economic Affairs, within the framework of Seed Money Project SMP16015

A Chinese version of this report has been published as 《荷兰经验对中国畜禽粪便治理的启发》，

白皮书 (间 杰, F.E. de Buisonjé, R.W. Melse, 2017，报告编号 1049，瓦赫宁根大学及研究中心 - 畜牧科学研究院)

Wageningen Livestock Research

Wageningen, September 2017

Report 1048 
J. Yan, F.E. de Buisonjé, R.W. Melse, 2017. White paper. Livestock Manure Treatment Technology of the Netherlands and Situation of China. Report 1048.

\section{Synopsis}

In this report an analysis is done on the environmental problems and policy related to animal manure in China and the Netherlands. Furthermore, available technologies and strategies for manure management and treatment are discussed. Finally, three manure management and treatment scenarios are described that could be applied in parts of China, taking into account regional differences.

This report can be downloaded for free at https://doi.org/10.18174/423982 (English) or at https: //doi.org/10.18174/423995 (Chinese) or at www. wur.nl/livestock-research (under Wageningen Livestock Research publications).

\section{(c) 2017 Wageningen Livestock Research}

P.O. Box 338, 6700 AH Wageningen, The Netherlands, T +31 (0)317 483953 ,

E info.livestockresearch@wur.nl, www.wur.nl/livestock-research. Wageningen Livestock Research is part of Wageningen University \& Research.

All rights reserved. No part of this publication may be reproduced and/or made public, whether by print, photocopy, microfilm or any other means, without the prior permission of the publisher or author.

The ISO 9001 certification by DNV underscores our quality level. All our research commissions are in line with the Terms and Conditions of the Animal Sciences Group. These are filed with the District Court of Zwolle.

Wageningen Livestock Research Report 1048 


\section{Table of contents}

2.1 Rapid growth and upscaling of the livestock sector $\quad 6$

2.1.1 Environmental effects 6

$\begin{array}{lll}2.2 & \text { Description of field trips for manure management } & 7\end{array}$

2.2.1 Visit to He Ao and He Yuan Dairy farm, Hei Longjiang province 7

2.2.2 Visit to Dingyuan Dairy farm in Luan Cheng, Hebei province 8

2.2.3 Visit to the breeding duck farm of Wens group, Guangdong province 8

2.3 New regulations to control manure pollution 9

2.3.1 Key articles of laws and regulations about treatment of livestock waste 9

2.3.2 Conclusion and recommendation $\quad 10$

2.4 Distribution of livestock manure production and arable farms in China $\quad 11$

2.4.1 Distribution of Livestock manure production 11

2.4.2 Distribution of different Terrain and arable farming $\quad 12$

$\begin{array}{ll}2.4 .3 \text { Conclusion } & 13\end{array}$

$3 \quad$ Manure production and regulations in the Netherlands $\quad 15$

$\begin{array}{lll}3.1 & \text { Surplus manure disposal, a license to produce } & 15\end{array}$

$\begin{array}{lll}3.2 & \text { Livestock farm figures and self-sufficiency } & 15\end{array}$

$\begin{array}{lll}3.3 & \text { Manure surplus figures } & 15\end{array}$

3.4 Application Standards for phosphate and nitrogen $\quad 16$

3.4.1 Application standards for phosphate 16

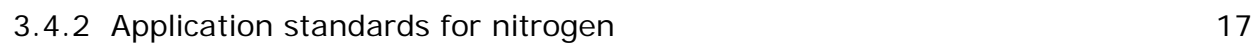

$\begin{array}{lll}3.5 & \text { Enforcement } & 18\end{array}$

3.6 Mandatory surplus manure processing and export $\quad 18$

$\begin{array}{lll}3.7 & \text { Concluding remarks } & 18\end{array}$

$\begin{array}{lll}5.1 & \text { Introduction } & 23\end{array}$

5.2 Scenario 1: Slurry application to grassland and arable farmland 23

5.2.1 Recycling nutrients $\quad 23$

5.2.2 No treatment and slurry application $\quad 23$

5.2.3 Simple mechanical separation $\quad 24$

5.3 Scenario 2: Biological waste water treatment system 25

$\begin{array}{lll}5.4 & \text { Scenario 3: Advanced separation systems } & 27\end{array}$

6.1 Requirements for adoption and implementation technologies in China 29

$\begin{array}{ll}6.2 & \text { Regions to apply different recommended scenarios } \\ \end{array}$ 



\section{Project description and aim}

The gross production of meat, eggs and milk in China was 87.06 million ton, 28.93 million ton, and 37.24 million ton respectively in 2014 (see Figure 1). As the production has increased, the size of the livestock farms have been enlarged greatly, and so has the production of the manure. It was reported the annual manure production from intensive livestock farms amounts to billions of tons per year nationwide, while less than $60 \%$ of the manure was effectively recycled and utilized due to high investment costs and lacking technology support ${ }^{1}$. Livestock manure is becoming one of the major sources causing environmental pollution which challenges the sustainable development of the livestock industry.

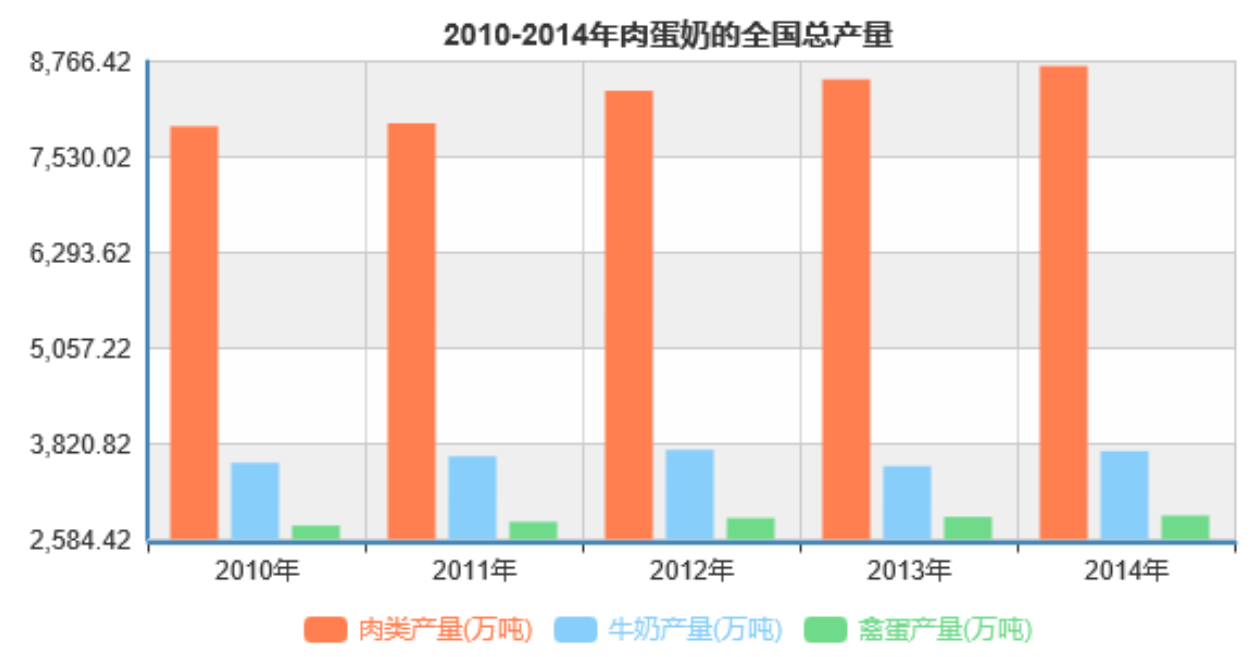

Figure 1 Gross production of meat, milk and eggs of China from 2010-2014, (unit: 10K Ton). Source: website of national bureau of statistics of China, http://data.stats.gov.cn).

With the background of such, the Seed Money Project of "Dutch livestock waste treatment system adaptation into Chinese situation" was proposed by a team of Wageningen UR researchers and granted in 2016 by the Agri \& Food top sector program of the Ministry of Economic Affairs of the Netherlands. The key aspects of the project are as follows:

- A Sino-Dutch Consortium will be built with companies and research institutions

- $\quad$ Field trips are carried out to both Chinese and Dutch livestock farms to get both sides understanding about each other's practice, after which benchmarking of the manure management will be made.

- $\quad$ To identify what technology and infrastructural system can be adapted to China (considering the legislation and market factors), make plans of how to adapt.

- $\quad$ As a follow up of this project, aiming at setting up a Sino-Dutch cooperation project (for example, Sino-Dutch livestock waste recycling Centre), financed by both Dutch and Chinese sides, to do the concrete design and adaptation of the systems and extension to markets.

The livestock waste discussed in this paper targets liquid manure or slurry (mix of urine, faeces, and cleaning water, usually with a water percentage of $90 \%$ or higher) produced at dairy, pig and poultry farms. The reason of such a targeting is that treatment and application of dry manure is ususally easier simpler while management and treatment of liquid manure often requires more complex technologies and logistics. In this paper we try to identify technologies and management scenarios that could be applied to animal slurry in China.

\footnotetext{
${ }^{1}$ http://www.moa.gov.cn/zwllm/zwdt/201609/t20160928_5294748.htm
} 


\section{Background information on China}

\subsection{Rapid growth and upscaling of the livestock sector}

Since the reform and opening policy of China in the 1970s, the livestock sector has been developing very fast. The percentage of gross value of livestock output in general agricultural output increased from $14.96 \%$ in 1978 to $31.70 \%$ in $2011^{2}$; meanwhile, the manure production also increased rapidly (Figure 2 shows an increase of about 20\% since 2000). At the same time, the recycling and land application of manure has become less and less since the 1960s, mainly because of the gradually replacement of organic fertilizer (manure) by chemical fertilizer ${ }^{3}$. The improper use of livestock manure has become a major source of diffused environmental pollution, and brought great challenge to the sustainable development of the animal husbandry industry. It is also estimated by the "Agricultural production outlook" that the amount of livestock manure production will reach 2.87 billion ton and 3.74 billion ton respectively by the year of 2020 and 2030 . Consequently, solutions for the treatment of such big amounts of manure are urgently needed.

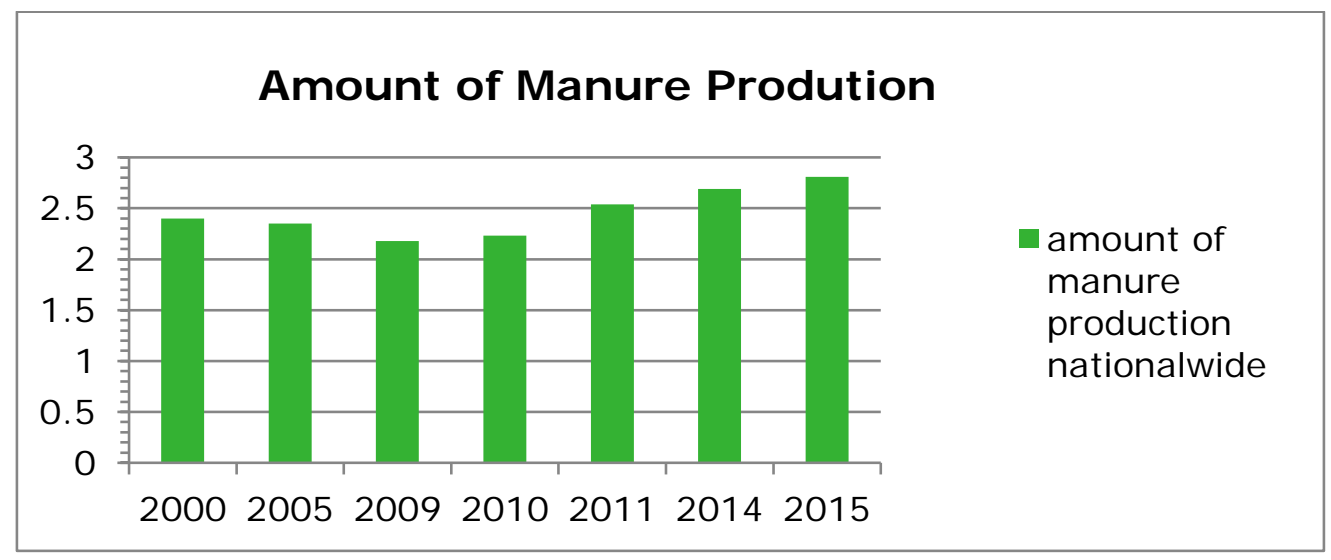

Figure 2 Production of livestock and poultry manure in China, 2000-2015 ${ }^{4}$.

\subsubsection{Environmental effects}

The major environmental effects from livestock farming and the handling of animal manure are ${ }^{5}$ :

1) Nitrate leaching to groundwater. Some soil microorganisms convert ammonium $\left(\mathrm{NH}_{4}{ }^{+}\right)$from manure to nitrate $\left(\mathrm{NO}_{3}{ }^{-}\right)$, the mobile form of nitrogen in soils. Nitrate may leach below the root zone and eventually reach ground water. When nitrate reaches surface waters this may (together with phosphorus, see below) lead to eutrophication. When ingested, nitrates present in food and water can be converted to nitrite $\left(\mathrm{NO}_{2}^{-}\right)$. Nitrite can interfere with the oxygencarrying capacity of red blood cells and produce a condition known as blue baby syndrome. Phosphorus run-off from agricultural land during or after manure application. Elevated levels of phosphorus in surface water contribute to harmful algae growths. This excessive algal growth leads to eutrophication. There are risks to human safety from the threat of harmful algae blooms near drinking water intakes, risks to fish communities due to low levels of dissolved oxygen, and the risk of beach fouling.

\footnotetext{
2 http://data.stats.gov.cn

${ }^{3}$ Analysis and solutions for waste management of intensive livestock industry in China, 2006, SuYang, Chinese Journal of Animal Science, Nr.14: 31-34.

4 Agricultural production outlook, 2014 No.1", “Academic journal for Agricultural environment sciences" 2014(3): 435-445, and "Agricultural engineering academic journal" 2013(1): 171-179.

${ }^{5}$ Handling animal manure; the struggle of the Netherlands, March 2016, Buisonjé, F.E. de; Melse, R.W.; Hoeksma, P.; World Environment 2016, Nr.2.
} 

can contribute to the eutrophication of surface waters. Sensitive crops can be damaged if they are cultivated near major ammonia sources. The deposition of ammonia on soils with a low buffering capacity can result in soil acidification and cation depletion. Furthermore, deposition of ammonia may lead to unwanted changes of natural ecosystems and vegetation of nature areas.

In the air, ammonia reacts with other compounds (e.g. sulphur dioxide from industrial sources) to form particulate matter (PM) with a diameter of 2.5 microns or less, which is referred to as fine dust $\left(\mathrm{PM}_{2.5}\right)$. This is of concern because the small size of the particles allows them to penetrate deep into the lungs.

Other negative environmental effects are the production of non- $\mathrm{CO}_{2}$ Green House Gasses like methane and nitrous oxide that contribute to Global Warming, and odour emissions from livestock and from manure application.

\subsection{Description of field trips for manure management}

The livestock waste SMP team made several field trips to dairy and poultry farms in China after the granting of the project.

\subsubsection{Visit to He Ao and He Yuan Dairy farm, Hei Longjiang province}

He Ao Dairy farm keeps more than 2000 dairy cows and is one of the 13 dairy farms belonging to Hegang farm of the Jiu San agricultural and farming administrative bureau; the Jiu San agricultural and farming administrative bureau owns 11 farms like Hegang farm.

The He Ao dairy farm, especially the manure management system, was designed by the Sifang Leo Company. There are two systems to treat manure; one is digestion and biogas system which can only operate during summer time. Temperature in winter time can be $-30^{\circ} \mathrm{C}$ in Hei Longjiang, which makes fermentation and production of biogas impossible. The biogas is mainly used to produce electricity to supply the dairy farm, and also for cooking and heating in company. The other system is separation of solid part and liquid part by sloping screen. Solid part is used for composting and then applied as organic fertilizer to arable lands, liquid part pumped into lagoon, and subcontracted to a service providing company who can treat it into concentrate (offered as a kind of high valued fertilizer for vegetables). One thing worth to mention is, this farm just purchased a slurry injector (produced in France) one month ago. They plan to apply the manure to the open field in the coming spring. This will be a new system to apply manure in China.

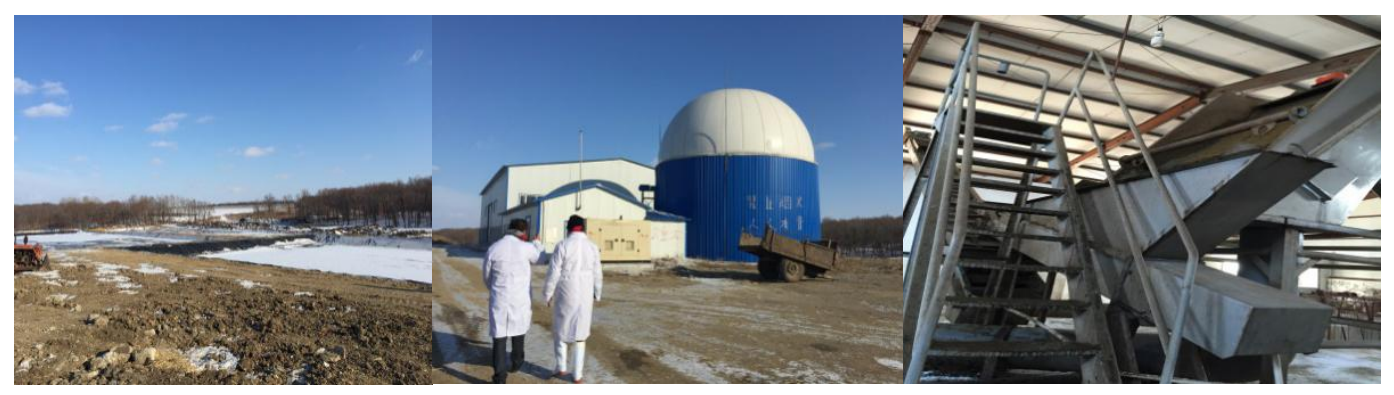

Figure 3 Manure management of He Ao Dairy farm, Hei Longjiang province.

In the same area, as the He Ao Dairy farm, the He Yuan farm also belongs to the Jiu san agricultural and farming administrative system. This farm was designed to accommodate 4800 cattle but the real amount of cattle was only 1200 by the time of visiting (April 2016). Dairy industry was having a hard time in China, that's why they reduced the number of cows.

The He Yuan Dairy farm also has two systems to treat the manure. The aerobic composting system, purchased from a Germany company, which can compost the solid part of the manure. Due to the low winter temperature, this system can only be used during summer and autumn time. One batch 
composting lasts for 3 months, even in summer, which means they can compost at most two batches per year.

The other system is a screw press separator for solid and liquid separation. The screw press can achieve drier solid part compared to the sloping screen, but it's more expensive and cannot stand long if too much sand is mixed in the manure. The separated solid part goes to composting, the liquid part goes to lagoon, and part of liquid also be reused to flush pipes. In this area, they apply the liquid to arable farms wen the growing season comes. The arable farm plot here is normally very large and flat, easy for manure transport and reuse.

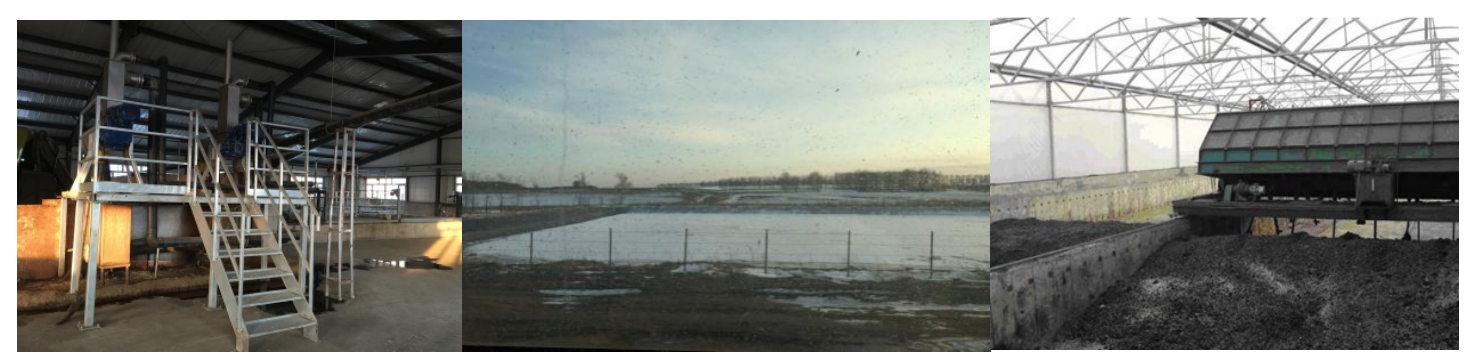

Figure 4 Manure management of He Yuan Dairy farm, Hei Longjiang province.

\subsubsection{Visit to Dingyuan Dairy farm in Luan Cheng, Hebei province}

The Dingyuan Dairy farm was designed for 2000 cows but only keeps 850 cows because of the low profit of dairy farming in recent years. The farm owner subcontract the cattle manure management to a contract service provider to sell the solid part of the cow manure, gaining around 3000 RMB per month. The liquid waste of the dairy farm, including waste water after flushing and urine of cows are separated from the solid part by sloping screen and are used to water nursery tree stocks in neighbourhood.

However, tree stocks nearby cannot consume so much liquid manure. As a solution, the dairy farmer managed to contract with his neighbourhood corn farmers to fertilize their $2500 \mathrm{mu}^{6}$ corn land for free, in return, maize farmers will sell the dairy farmer corn in cheaper price than market. This model is getting popular in Hebei area.

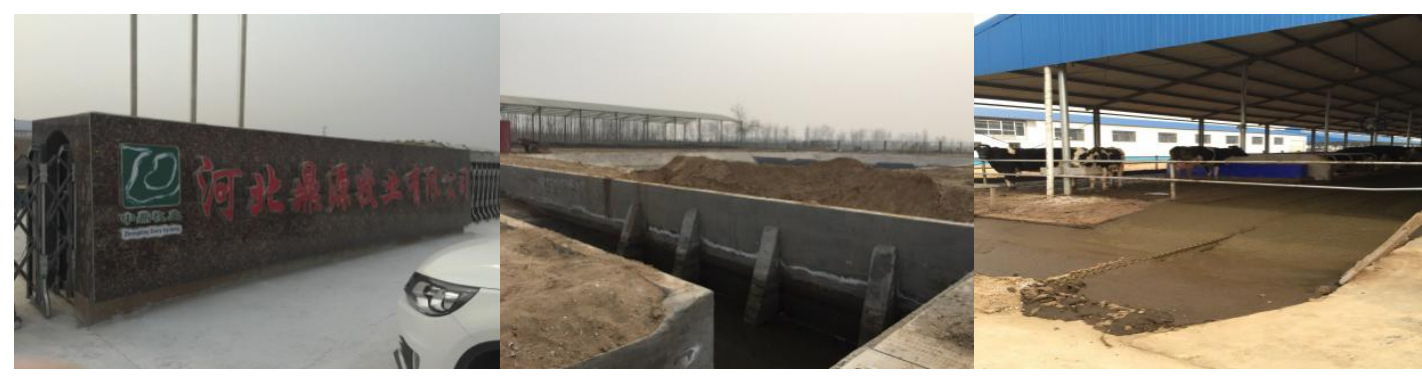

Figure 5 Manure management of Dingyuan Dairy farm, Hebei province

\subsubsection{Visit to the breeding duck farm of Wens group, Guangdong province}

In this high-tech demonstration plant, the liquid manure from 2 million breeding ducks is treated by biological waste water treatment system (after biogas generation in two lagoon digesters). Wens Group is using the same biological waste water treatment system as is commonly seen in urban sewage treatment, i.e. treating duck manure instead of sewage water. B before the biological treatment, however, the duck manure first goes through two simple bio-digesters to produce biogas. Then the digestate fluid is treated via nitrification and denitrification. Finally, the treated water is discharged into an artificial river outside the duck farm.

\footnotetext{
${ }^{6} 1$ ha $=15$ mu.
} 

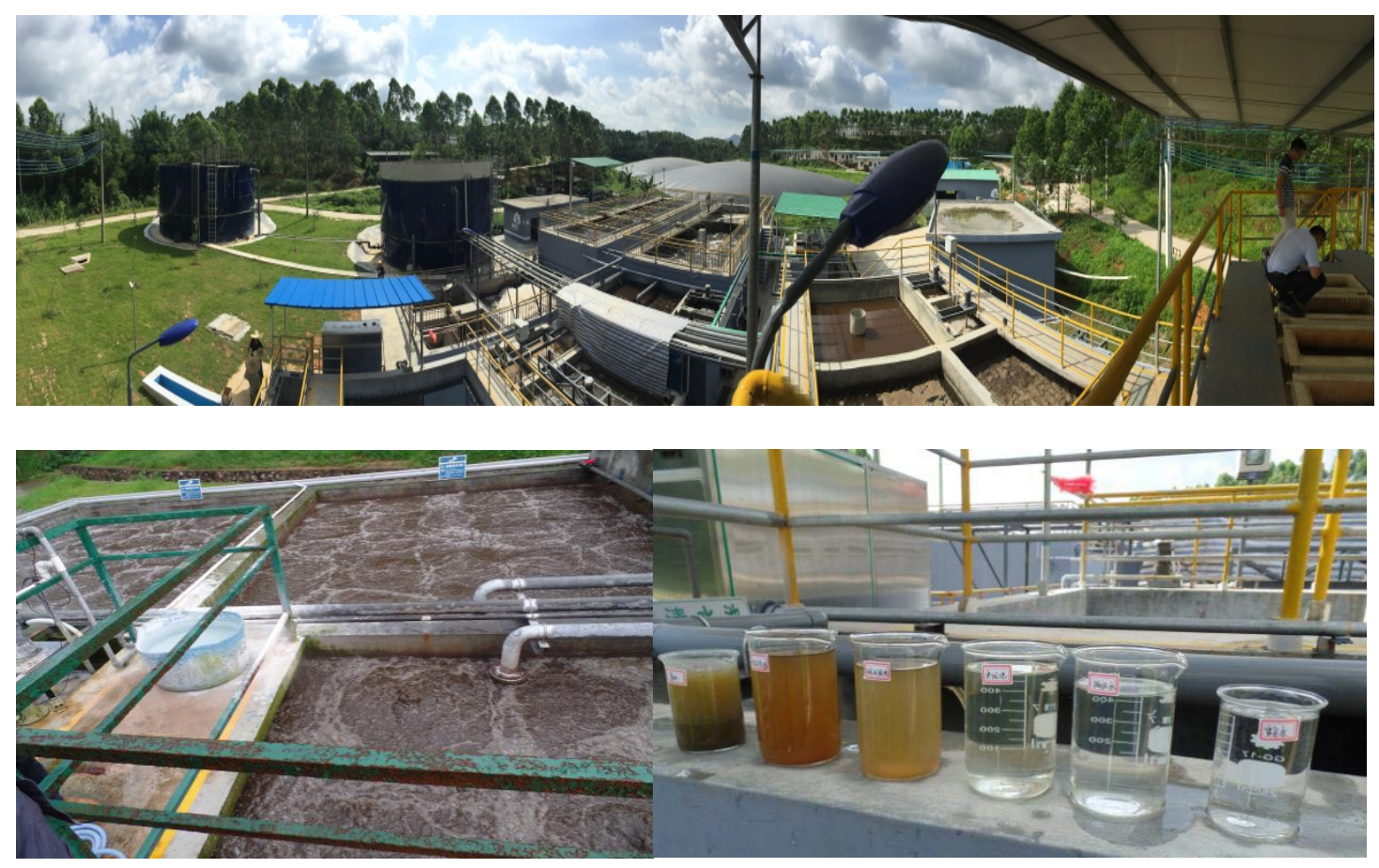

Figure 6 Manure management of the duck breeding farm of the Wens group, Guangdong province.

\subsection{New regulations to control manure pollution}

\subsubsection{Key articles of laws and regulations about treatment of livestock waste}

Since 2014, many new laws, regulations and plans were issued to protect environment, articles referring to treatment of livestock manure are collected in Table 1 below.

Table 1 Key articles of laws and regulations about treatment of livestock waste.

\begin{tabular}{|c|c|}
\hline & Law, regulation \& plan \\
\hline \multirow[b]{2}{*}{ Laws } & $\begin{array}{l}\text { Environmental Protection Law (revised 2015) } \\
\text { Citizens, legal persons and other organizations shall have the right and access to } \\
\text { achieve environmental information, to participate in environmental protection } \\
\text { activities, and to supervise and report the illegals. } \\
\text { Farmers and owners operating livestock farms or slaughter houses shall take } \\
\text { measures to deal with livestock manure, dead bodies and waste water in } \\
\text { scientifically sound way. } \\
\text { Departments of environment protection at or above county level are entitled to } \\
\text { limit discharge of pollution by various means, like reducing production of } \\
\text { farms/enterprises, or even closing and shutting down } \\
\text { Government encourages clean production and recycling of resource. }\end{array}$ \\
\hline & $\begin{array}{l}\text { Regulation for pollution control of scale livestock farms } \\
\text { (issued } \mathbf{2 0 1 4} \text { ) }\end{array}$ \\
\hline
\end{tabular}




\begin{tabular}{|c|c|}
\hline & $\begin{array}{l}\text { If the discharge or emission of livestock manure does not conform to the related } \\
\text { national standards or index of total amount control, the company or farm can be } \\
\text { fined 50,000RMB at most. }\end{array}$ \\
\hline \multirow{5}{*}{$\begin{array}{l}\text { National } \\
\text { planning } \\
\text { and } \\
\text { regulations }\end{array}$} & $\begin{array}{l}\text { Sustainable development planning for agriculture from year } 2015 \text { to } \\
\mathbf{2 0 3 0} \text { (issued 2015) } \\
\text { Governments support scale livestock farms to rebuild or construct according to } \\
\text { recommended standards. The aim is to achieve the reuse or recycle percentage } \\
\text { of livestock waste to } 75 \% \text { and } 90 \% \text { by the year of } 2020 \text { and } 2030 \text { respectively, } \\
\text { to gradually increase the recycling of the manure resources in terms of ecological } \\
\text { digestion or up-to-standard discharge in scale livestock farms. } \\
\text { To set up manure treatment demonstration pilots in county level in provinces or } \\
\text { districts of livestock advantage. }\end{array}$ \\
\hline & $\begin{array}{l}\text { Water pollution prevention action plan (issued 2015) } \\
\text { Manure storage, treatment, and recycling facilities are compulsory for scale } \\
\text { livestock farms by the year of } 2016 \text {. Areas with intensive Household livestock } \\
\text { farms shall carry out separate collection and centralized treatment and utilization. }\end{array}$ \\
\hline & $\begin{array}{l}\text { Soil pollution prevention action plan } \\
\text { (issued 2016) }\end{array}$ \\
\hline & $\begin{array}{l}\text { I ntegrated reform plan for promoting ecological progress } \\
\text { (issued 2015) } \\
\text { A system will be established to utilize farming, livestock, and aquaculture waste } \\
\text { and achieve the effective integration and circulation of crop farming, husbandry, } \\
\text { and aquaculture. }\end{array}$ \\
\hline & $\begin{array}{l}\text { Action plan for zero- growth of artificial fertilizer application by } \\
\mathbf{2 0 2 0} \text { (issued } \mathbf{2 0 1 5} \text { ) } \\
>\quad \text { Manure nutrient recycling is less than } 50 \% \text { in China, and straw nutrient recycling } \\
\text { is less than } 35 \% \text {. } \\
\text { Overusing of artificial fertilizer not only increase the cost of agricultural } \\
\text { production, but also cause compaction and soil acidification of arable land. } \\
\text { By } 2020, \text { Manure nutrients application to arable fields shall reach the rate of } 60 \\
\text { percent, } 10 \text { percentage points increased from now. } \\
\text { By } 2020 \text {, fertilization by machineries shall take more than } 40 \% \text { of main crops } \\
\text { acreage, increased by } 10 \text { percentage points from now. } \\
\text { By } 2020, \text { soil organic matter content of arable land shall be increased by } 0.2 \\
\text { percentage. } \\
2015 \text { to } 2019 \text {, the annual growth rate of artificial fertilizer use will gradually be } \\
\text { controlled within } 1 \% \text {; by } 2020 \text {, artificial fertilizer use to the main crop aims to } \\
\text { zero growth. }\end{array}$ \\
\hline
\end{tabular}

\subsubsection{Conclusion and recommendation}

With the intensively issued laws and policies, the Chinese government is determined to lead China into a cleaner future. When looking into details of the articles, we can get the clue about how the central government plans to tackle the livestock waste problem:

The livestock manure is more often called manure resource instead of waste, which means recycling and reuse are encouraged by the government. 
- $\quad$ Application to the field, biogas production and composting into organic fertilizer are the concrete methods recommended by the government, however no maximum application limits to arable land have been defined.

- $\quad$ Untreated manure is forbidden to be discharged into the environment.

- $\quad$ Government will support to set up pilot projects on manure treatment/recycling; to rebuild livestock farms to reach the standards or capacity in manure treatment.

Compaction, acidification and salinification are major problems of the soil condition in many parts of China. Bringing organic manure back to the soil will increase soil quality.

To summarize, reuse and recycling of manure to arable fields is believed by the central government as a right way to deal with both the manure problem of the livestock industry and the soil quality problem of crop planting. However, the government also states that "untreated manure is forbidden to be discharged into the environment", which leads to a lot of arguments in practice of manure reuse and recycling. Firstly the term "untreated manure" used here is a vague definition. For example, physical separation of the slurry into solid and liquid might be regarded as a kind of treatment, but it would not necessarily reduce any presumed risk to environment. Furthermore, the reuse of untreated manure by application to arable land with the aim of providing nutrients to the crops might not be considered as "discharge of pollution" as long as it is being applied in the right way, right dose and right season. Last but not least, the discharge standards for waste water that are used in China were established to regulate discharge of industrial and municipal waste water (a maximum COD of 120 $\mathrm{mg} / \mathrm{L}$, a maximum $\mathrm{N}$-total concentration of $20 \mathrm{mg} / \mathrm{L}$. and a maximum of P-total of $5 \mathrm{mg} / \mathrm{L}^{7}$ ), may not suitable for regulating the use of livestock manure as a fertilizer. Therefore the regulations need to be adapted further to elaborate under what conditions untreated manure can be applied to arable lands, what techniques (if any) are compulsory to treat the manure with, and what standards shall be achieved after the treatment. As mentioned previously, experiences from many countries, like the USA and the Netherlands, proved that untreated manure can be safely used for fertilization of arable lands if it is applied in the right way, right season, right dose and for the right crop.

\subsection{Distribution of livestock manure production and arable farms in China}

The fast development and scale increase of livestock industry, and the gradual separation of animal husbandry away from crop growing are the two major reasons for the more and more serious problem of manure management in China. Some studies show that small-scale livestock farms are more inclined to reuse manure as nutrients for soil application but even so, large scale livestock farms normally cannot find enough arable farms thatare capable to take in the huge amount of manure that is produced. That's the reason we see the relative amount of recycling of livestock manure got down when livestock farms scaleup or merge together during the past decades ${ }^{8}$. To improve the recycling, it is necessary to make an analysis about the distribution of livestock manure production and distribution of arable farms across China, and then identify strategy and technologies to bring nutrients back to soil, based on the results of manure analysis.

\subsubsection{Distribution of Livestock manure production}

The livestock manure production here includes manure from pig, dairy, beef, layer chicken and broiler farms. From a statistics data of 2013 by Yang Shiqi, Han Ruiyun, and Liu Chenfeng (Figure 7), we can draw the following conclusions regarding livestock manure production all over China:

- $\quad$ The top four provinces that have the highest manure production are Shandong, Henan, Hebei, Sichuan;

- $\quad$ Guangdong, Fujian, Hunan, Anhui and Jiangsu belong to the second highest group of manure production regions.

\footnotetext{
7 http://huanbao.bjx.com.cn/news/20160108/699613.shtml

8 仇焕广，廖绍攀，井月，奕江. 我国畜禽粪便污染的区域差异与发 展趋势分析.环境科学，2013，34(7): 2766-2774. Qiu H G, Liao S P, J ing Y, Luan J. Regional differences and development tendency of livestock manure pollution in China. Environmental Science, 2013, 34(7): 2766-2774 (in Chinese).
} 
Inner Mongolia and the northeastern three provinces (including provinces of Liao Ning, Jilin and Hei Longjiang) belong to the third highest group of manure production regions of China.

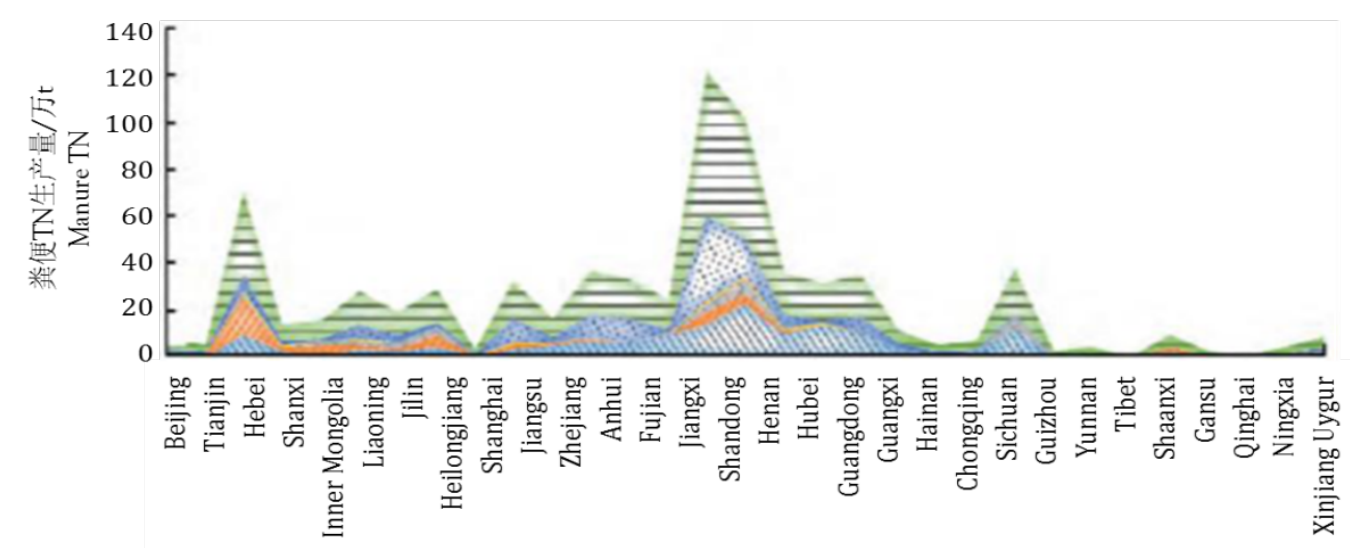

省市自治区 Provinces \& Municipalities \& Autonomous Region

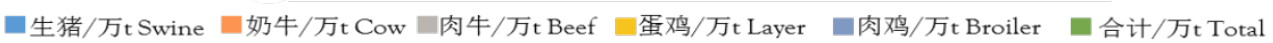

Figure 7 Total nitrogen production of Livestock manure of different provinces and autonomous regions of China 2013 . Unit on vertical axis: 10,000 ton N/year. ${ }^{9}$

\subsubsection{Distribution of different Terrain and arable farming}

In terms of terrain, China can be laid out into Plateau, basin and plain areas:

- $\quad$ There are 4 plateaus in China, which mainly cover provinces of Qinghai and Tibet (Tibet plateau), Inner Mongolia and Ningxia (Inner Mongolia plateau), Shanxi and Shaanxi (loess plateau), Yunnan and Guizhou (Yunnan-guizhou plateau). Among them, the Inner Mongolia plateau is quite flat with good transportation situation. Rice, potato, maize and forage grasses are the main crops there. According to the data from Figure 7, Inner Mongolia and Ningxia province are also quite developed in livestock sector, especially in dairy farming, which makes the two provinces ideal place to carry out nutrient recirculation between livestock and crop production.

- $\quad$ Large part of Xinjiang and Sichuan provinces fall into the basin area. Xinjiang owns a vast territory with flat topography in the basin area. With a special land policy (Xinjiang Production and Construction Corps is governing very large scale farmland there) large scale crop production is quite common, which provides opportunities for bringing manure nutrients back to the soil. Although Sichuan is a big livestock production province, the region is full of mountains and water surface, only $5.3 \%$ of the province is flat area, so transportation and mechanical land cultivation is difficult in this area. This means that large-scale manure transportation and application is difficult, in general. In this sense, techniques are in demand to reduce the manure volume efficiently so that the concentrated nutrients can be brought back to arable land or transported to other regions.

- $\quad$ Plains are mainly located in northeast China (Heilongjiang, Jilin, Liaoning and part of Inner Mongolia); north China (Beijing, Tianjin, Shandong, Hebei, Henan, north Anhui and north Jiangsu); as well as the middle and downstream of Yangtze River (covering Hubei, Hunan, south Anhui, South Jiangsu, Zhejiang etc.). All the above plain provinces are important areas in both livestock and crop production. Therefore, technology and knowledge is needed to evenly distribute the manure in farmlands as it will not only solve the issue of the animal waste, but also improve the soil quality and fertility, if applied correctly. The difference is, provinces belong to middle and downstream of Yangtze River (Hubei, Hunan, Anhui, Jiangsu, and Zhejiang) grow rice as major crop, while the other provinces grow more wheat, maize and other dry crops. Paddy rice farms are relatively difficult for mechanical application of any form of manure, either in slurry or composted dry manure. Main reason is the ridge of paddy

\footnotetext{
9 杨世琦，韩瑞芸，刘晨峰，省域尺度下畜禽粪便的农田消纳量及承载负荷研究。中国农业大学学报 2016,21 ( 7 ) : 142-151。Yang Shiqi， Han Ruiyun, Liu Chenfeng, Study on the given amount per unit field and load capacity of livestock and poultry manure at provincial scale. Journal of china agricultural university, 2016, 21 ( 7 ) : 142-151
} 
rice farm obstructs the operation of trucks and machines, as shown in the picture below (Figure 8). When irrigation channels are available, diluted slurry can be applied with the irrigation water.

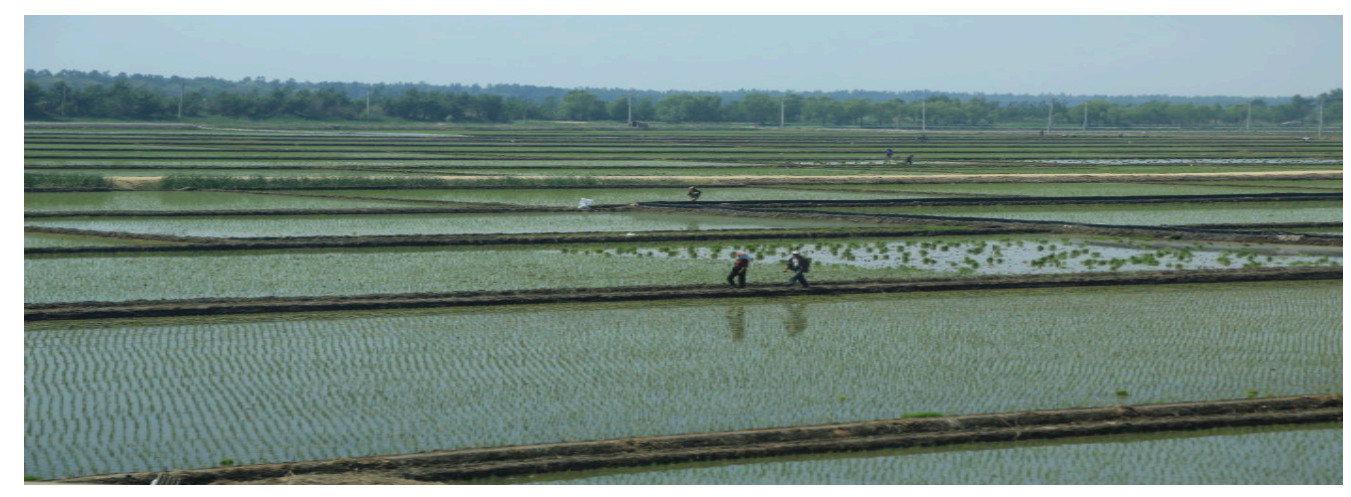

Figure $8 \quad$ Typical paddy rice farms in downstream of Yangtze River.

Guangdong and Fujian are located in southeast of China along the coastline. Mountains and hilly lands take about $80 \%$ of the area of the two provinces. Arable lands are scattered into very small fragments there, average farming area per household is $0.37 \mathrm{Mu}, 1 / 4$ of the national level. Both above reasons make it very difficult to do any machinery work in the farms. These two provinces belong to the top of the national rank in livestock production, but the unfavourable topography makes scale manure application extremely difficult. Similar to Sichuan, ways must be found to reduce the volume and remove the nutrients.

\subsubsection{Conclusion}

As livestock husbandry nowadays has a very large scale, manure management practices have to deal with managing large amounts of manure within a quite short time. Technologies are for large scale animal farms to manage, treat and distribute the livestock manure and manure products and bring them to arable land.

Two questions should be considered when bringing animal manure to the arable land in areas that seem to have favourable conditions for manure application (as indicated in section 2.5.2):

1) whether the land size and land policy restrict the method/equipment for manure application. Average farming area per farmer is only $1.35 \mathrm{mu}^{10}$ in China. Ridge is made to be the land division mark (see Figure 8), and different crops are produced in different small divided farmlands, all the factors make it difficult for any mechanical work on large scale;

2) Whether the variety of crop is suitable for manure application. One example is paddy rice, the main crop in the middle and down streams of the Yangtze River. The water-covered paddy rice farms are hard to be manured comparing to those dry land crops in terms of technology application and time limits.

When having above in mind, and taking synergetic factors into account, such as distribution of livestock manure production, distribution of arable farms, major crops (dry or paddy) as well as topography of arable farm area, we can identify three types of regions that suit for different manure treatment technologies. they are marked with different colours in the map of Figure 9.

Yellow marked place consists of provinces of Xinjiang, Hei Longjiang, Jilin, Liaoning, Hebei, Shandong, Henan and two autonomous regions of Inner Mongolia and Ningxia. These provinces produce a large amount of livestock manure. They produce dry-land crops in an extensive way and landscape is rather flat. Small farm lands are gradually being centralized and merged by the encouragement of government. Therefore, application of large amounts of manure (products) to local arable farm is feasible in these areas.

\footnotetext{
101 ha $=15 \mathrm{mu}$.
} 
Green marked region includes provinces of Jiangsu, Anhui, Zhejiang, Jiangxi, Hunan and Hubei provinces. These provinces are in the middle and lower reaches of the Yangtze River with plenty of rainfall and an extensive river network and have paddy rice as the major crop. Further studies are necessary to find out on what scale and in what manner application of manure products are possible considering the special production method on paddy rice farms. In other words, if large scale application of manure in mechanical way proves not to be feasible, other technologies should be considered to reduce manure volume or/and to transport the manure to other regions.

Blue marked place are Fujian, Guangdong and Sichuan provinces. Direct application or reuse of manure is very hard to the arable farm in this area due to topographic reasons. Technologies are in demand to decrease the volume of manure greatly, or produce manure into fertilizer products.

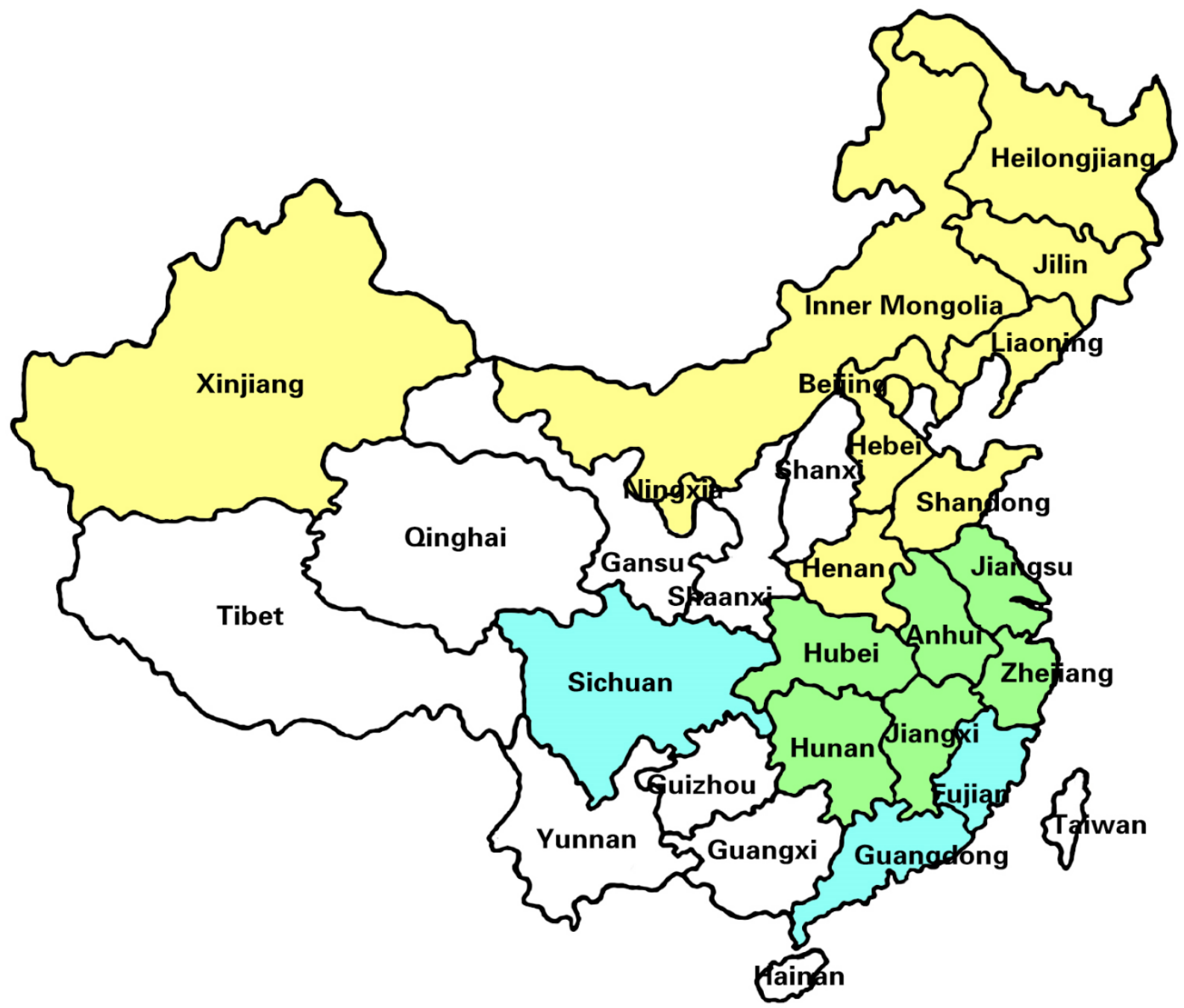

Figure 9 Chinese regions have different opportunities and demands towards manure treatment and manure management technology. Colours are explained in the text. 


\section{Manure production and regulations in the Netherlands}

\subsection{Surplus manure disposal, a license to produce}

The manure distribution chain in the Netherlands consists of three links:

- $\quad$ the livestock farm with a manure surplus,

- the manure transport company,

- $\quad$ the manure receiving farm (arable farm or livestock farm with enough land).

For environmental reasons, surplus manure in the Netherlands has to be transported from the animal farm to another farm with sufficient more space for manure application. The livestock farmer has to pay approx. $€ 10$ to 23 per ton to the transport company. The transport company will pay approx. $€ 3$ to 10 per ton to the manure receiving arable farmer; the difference must cover the costs of transportation.

This manure distribution and disposal system is costly for manure producing farms while manure receiving farms profit from free fertilizer with extra cash. This is considered a license to produce for livestock farms with a manure surplus.

\subsection{Livestock farm figures and self-sufficiency ${ }^{11}$}

In the Netherlands, there are approximately 17,000 dairy farms with a total of 1.6 million milking cows that produce a total quantity of over 13 billion kilograms of milk per year. An average dairy farm in the Netherlands (family farm) has around 100 milking cows and around 50 hectares of agricultural land. The average milk production per cow is 8,100 litres per year.

The Dutch pig industry consists of about 4,800 pig farms with a total of 12 million pigs and a gross domestic production (slaughtering and exports) of about 24 million animals per year.

The Dutch layer poultry sector consists of approx. 1,000-layer farms with a total of 36 million laying hens that produce around 11 billion eggs annually. The average farm size is around 35,000 laying hens.

The Dutch broiler industry consists of 580 broiler farms which jointly hold over 47 million broilers. The average size of a broiler farm is 81,000 birds. The annual production of broiler meat is around 1 million tons.

The degree of self-sufficiency in the Netherlands is around $300 \%$ for most animal products; this means that the bigger part of the annual production of milk products, meat and eggs is exported.

\subsection{Manure surplus figures}

Most dairy farms in The Netherlands have land (50 hectares per farm on average), but most pig and poultry farms do not. Therefore dairy farms can apply part of the manure to their own land and only the surplus part of the cattle manure has to be transported to other (arable) farms. However, most pig and poultry farms do not have any land at all, which means that virtually all pig and poultry manure has to be transported to other farms. In Table 5 the average composition of different manures (cattle, pig, poultry) and solid fractions are shown.

In 2014, $78 \%$ of the dairy farms produced more manure than could be applied on their own land, resulting in a phosphate surplus of almost 12 million tons of slurry (Table 2 ).

\footnotetext{
${ }^{11}$ Source: RaboBank, 2016.
} 
Approximately $90 \%$ of all animal manure in the Netherlands is slurry (the liquid mixture of feces, urine and cleaning water, collected under slatted floors). This concerns more than 70 million tons per year; about $80 \%$ consists of cattle slurry and $20 \%$ of pig slurry. 2015 was the first year in the history of the Dutch manure surplus that more cattle slurry than pig slurry was transported in the Netherlands (Table 2), as a result of increasing cattle numbers. In 2015, more than 620,000 truckloads of slurry were transported, totalling about 22 million tons of slurry; more than half were cattle slurry, the remainder being pig slurry.

Manure distribution from livestock farms with a nutrient surplus to arable farms that can use the nutrients in crop production is an essential element of the Dutch agricultural system . Synthetic fertilizers are increasingly being replaced by nutrients in animal manure as the fee that arable farmers receive for using manure has increased in recent years.

Table 2 Manure transport in the Netherlands in 2015.

\begin{tabular}{|lcc|}
\hline Manure type & $\begin{array}{l}\text { Number of truck } \\
\text { loads per year }\end{array}$ & $\begin{array}{l}\text { Manure quantity } \\
\text { (million tons/ year) }\end{array}$ \\
\hline Cattle slurry & 322,000 & 11.6 \\
Pig slurry & 300,000 & 10.2 \\
Poultry manure & 55,000 & 1.6 \\
Horse manure & 119,000 & 2.1 \\
Others & 107,000 & 3.3 \\
Total & $\mathbf{9 0 3 , 0 0 0}$ & $\mathbf{2 8 . 8}$ \\
\hline
\end{tabular}

In 2015, 5.7 million tons of manure were not applied on agricultural land in the Netherlands, but used by households (in private gardens) or exported and subsequently used on agricultural land in neighbouring countries.

\subsection{Application Standards for phosphate and nitrogen}

The cornerstone of the Dutch manure policy is a system of application standards for both nitrogen and phosphate on agricultural land. This means that maximum amounts of phosphate and nitrogen are defined that may be applied to a hectare of arable land. For nitrogen, an EU application standard exists (see below) and most EU countries assume that the application standard for nitrogen offers enough protection against over application of phosphate as well. In the Netherlands, however, a separate application standard for phosphate is applied in addition to the EU nitrogen application standard.

The phosphate application standards were introduced in 1987 (Table 3) whereas the EU nitrogen application standards were introduced in 1998. Final application standards for phosphate were reached in 2015 and for nitrogen in 2006 (with the exception of some recent minor changes in the so-called 'derogation' for cattle manure on farms with $>80 \%$ grassland, see the next section).

\subsubsection{Application standards for phosphate}

The introduction of phosphate application standards in 1987 concerned:

the maximum amount of phosphate (P2O5) per hectare for arable land, grassland and corn fields respectively (see Table 3); both phosphate from manure and from synthetic fertilizer are taken into account,

- $\quad$ the period of manure distribution: from September until February (the 'cold season') it is forbidden to spread manure on the land to prevent leaching and run-off, the manner of application: to reduce ammonia and odour emissions, manure is incorporated directly in or under the soil (e.g. slurry injection instead of surface spreading). 
Table 3 Maximum application standards for phosphate* in the Netherlands between 1987 and 2015, in kg P2O5/hectare/year (1 hectare = $15 \mathrm{mu}$ ).

\begin{tabular}{|l|c|c|c|}
\hline Year & \multicolumn{3}{|c|}{ Land use } \\
\hline & Arable land & Grassland & Corn fields \\
\hline $\mathbf{1 9 8 7}$ & 125 & 250 & 350 \\
\hline $\mathbf{1 9 9 1}$ & 125 & 250 & 200 \\
\hline $\mathbf{1 9 9 5}$ & 110 & 150 & \multirow{2}{*}{ See Arable land } \\
\hline $\mathbf{1 9 9 8}$ & 100 & 120 & \\
\hline $\mathbf{2 0 0 0}$ & 85 & 85 & \\
\hline $\mathbf{2 0 0 2}$ & 80 & 80 & \\
\hline $\mathbf{2 0 1 5}$ & $50-75^{* *}$ & $80-100^{* *}$ & \\
\hline
\end{tabular}

* Sum of phosphate from manure and synthetic fertilizer.

**: Final standards, depending on soil phosphate status, to be confirmed by soil analysis

\subsubsection{Application standards for nitrogen}

Although the nitrogen application with manure was indirectly controlled by the phosphate application standards, since nitrogen and phosphate levels in manure are linked to each other, the application of synthetic nitrogen fertilizer was not yet taken into consideration.

Therefore, in 1998 the MINeral Accounting System (MINAS) was introduced in the Netherlands. MINAS consisted of a nutrient bookkeeping system at the farm level and addressed both nitrogen ( $N$ ) and phosphate (P2O5), both from manure and from synthetic fertilizer. The aim was to reach a balance at the farm level between nutrient inputs and outputs (the outputs being the crops), taking acceptable nutrient losses into account. The difference was called the surplus (or loss) and was compared with maximally allowed surplus standards. The acceptable losses were set to $180 \mathrm{~kg} \mathrm{~N} /$ hectare/year for grassland and $100 \mathrm{~kg} \mathrm{~N} /$ hectare/year for arable land. Farmers were taxed $€ 2,30$ for every $\mathrm{kg} \mathrm{N}$ and $€$ 9,00 for every kg P205 exceeding the standard.

The MINAS-system with calculated acceptable losses was abolished in 2003, after the EU court ruled that the Netherlands had to comply with the EU Nitrates Directive, allowing for a maximum application standard of $170 \mathrm{~kg}$ of nitrogen from animal manure per hectare per year (both for grassland and arable land). For cattle farms with more than $80 \%$ of permanent grassland, higher nitrogen application rates ( 230 or $250 \mathrm{~kg} \mathrm{~N} /$ hectare/year from manure) are allowed; this is the so-called 'derogation' that is based on the high nitrogen uptake of highly productive grassland in the Netherlands (and in some other EU member states). The EU Nitrates Directive only deals with nitrogen from manure, the application of synthetic nitrogen fertilizer is not taken into account.

Since the introduction of the Nitrates Directive in 1991, the manure policy in the Netherlands was further tightened. The EU Water Framework Directive was introduced in 2000, aimed at protecting the quality of surface waters with regard to nitrogen, phosphate and many other chemical pollutants, like pesticides, herbicides and heavy metals. Because the Netherlands did not yet comply with the environmental goals with regard to the quality of ground- and surface waters, additional measures had to be taken, such as:

- crop specific nitrogen application standards (in addition to the phosphate application standards), as the sum of nitrogen from manure and from synthetic fertilizer, based on crop nitrogen uptake ${ }^{12}$,

- $\quad$ shortening the period for manure application (February-August, i.e. 7 months),

- $\quad$ mandatory planting of a catch crop, after corn on sandy soil, in order to decrease nitrate leaching,

- $\quad$ A further reduction of phosphate application standards (final standards were reached in 2015, Table 3).

\footnotetext{
${ }^{12}$ A table with nitrogen application standards per crop can be found here: http://www.rvo.nl/file/tabel-1stikstofgebruiksnormen-2015-2017-1.
} 


\subsection{Enforcement}

Although the MINAS system was partly abolished, the administrative bookkeeping system and data base that was introduced with MINAS is still in place and plays an important role in enforcement. For both nitrogen and phosphorus a balance on farm level is calculated, based on all inputs and outputs. This means e.g. that all feed entering the farm, and all animal products and truckloads of manure leaving the farm are weighed, registered, and (if no standard compositions are available) analysed in a laboratory.

Essential in the manure and fertilizer legislation is that the farmers and transporters involved are to submit their relevant farm and manure transport data, which are connected with each other by the government and on the basis of which specific controls are being carried out in retrospect. The Ministry of Economic Affairs monitors, both administratively and by supervision in the field, manure transport operations, data registration, manure and fertilizer applications, results of mandatory chemical analyses of manure nitrogen and phosphate levels in approved laboratories, recording of all the data in a database and linking all data. Breaking the general rules results in an economic offence, which can be investigated and indicted under criminal law.

\subsection{Mandatory surplus manure processing and export}

In 2014, new legislation was introduced, that obliges farmers to export excess manure. Every livestock farm with a phosphate surplus has to process and export a percentage of this surplus. These percentages will increase annually until the desired balance between manure phosphate production and available agricultural land or crop uptake in the Netherlands is reached. It is expected that this balance will be reached before 2020. The percentages are higher for farms in the livestock concentration areas (South and East) than for farms elsewhere in the Netherlands (Table 4). Manure exports are expressed in kilograms phosphate.

Table 4 Mandatory percentages for surplus manure phosphate processing followed by export in different livestock concentration areas in the Netherlands in different years, based on individual livestock farm phosphate surplus.

\begin{tabular}{|l|l|l|l|l|}
\hline Region & $\mathbf{2 0 1 4}$ & $\mathbf{2 0 1 5}$ & $\mathbf{2 0 1 6}$ & Final 2018 ? \\
\hline Concentration area South & $30 \%$ & $50 \%$ & $55 \%$ & $70 \%$ \\
\hline Concentration area East & $15 \%$ & $30 \%$ & $35 \%$ & $50 \%$ \\
\hline Rest of the Netherlands & $5 \%$ & $10 \%$ & $10 \%$ & $10 \%$ \\
\hline
\end{tabular}

Manure processing into products with high nutrient levels and a low moisture content can contribute to an improved efficiency of the manure distribution system including export.

\subsection{Concluding remarks}

Major environmental improvements were possible by limiting nutrient losses to air and water by introducing nutrient application standards and improvements in manure application technology. This could only be achieved by creating a nationwide infrastructure for slurry transport and liquid manure application. Since the 1980s, ammonia emissions and nitrate leaching were drastically reduced and the quality of groundwater and surface waters has drastically improved.

A prerequisite for success is a coherent system of clear and realistic regulatory standards (e.g. nutrient application standards for agricultural land) which can be adapted as required by local circumstances. An efficient logistics system for manure storage and distribution is also indispensable, as well as accurate records, monitoring, administration and enforcement. 


\section{Popular manure management technologies in the Netherlands}

In the Netherlands, a set of different manure management technologies is applied. The most popular technolgies, depending on the particular situation and circumstances, are:

1. $90 \%$ of all manure in the Netherlands:

Low emission application of untreated liquid and solid manure (and liquid digestate) as fertilizer on agricultural land within the Netherlands).,

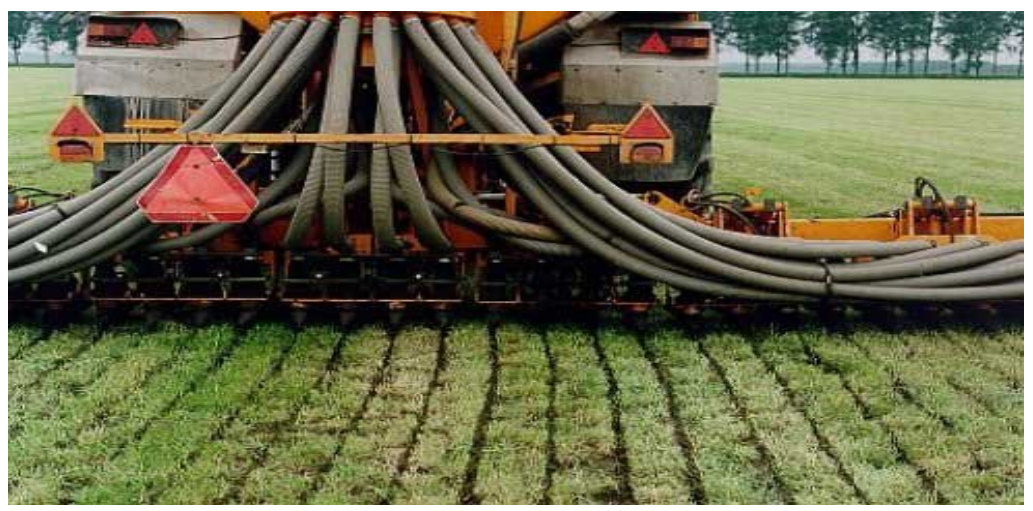

Figure $10 \quad$ Low emission slurry application on grassland.

2. $5 \%$ of all manure in the Netherlands:

Mechanical solid-liquid separation of slurry and transport/export of the solid fraction to agricultural land in the Netherlands or other EU member states (Germany, Belgium, France); the liquid fraction is mostly applied to local arable land.

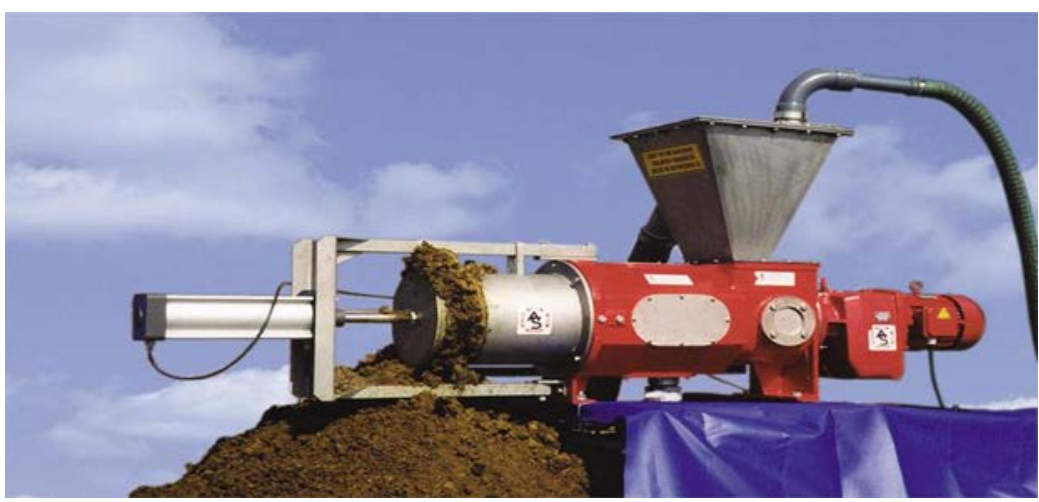

Figure 11 Mechanical slurry separation with screw press. 
3. $1 \%$ of all manure in the Netherlands:

Membrane filtration of liquid manure fraction using reverse osmosis and application of ROconcentrate (liquid NK-fertilizer) as fertilizer on agricultural land in the Netherlands.

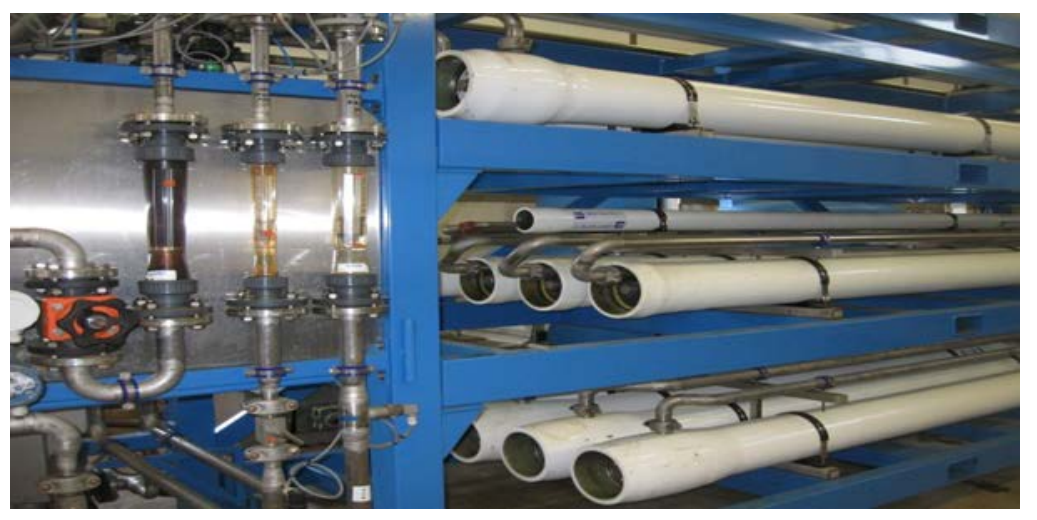

Figure 12 Reverse osmosis installation for production of NK-concentrate.

4. $1 \%$ of all manure in the Netherlands:

Biological treatment (nitrification/denitrification) of liquid fraction of veal calf slurry and application of the solid fraction and sludge as fertilizers on agricultural land in the Netherlands.

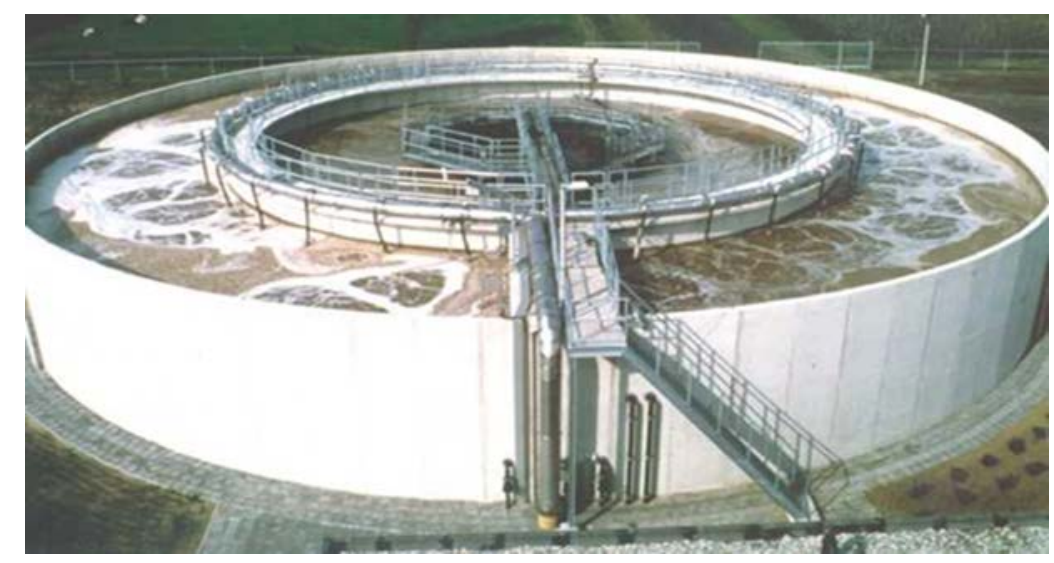

Figure 13 Biological treatment of liquid fraction of veal calf slurry.

5. $1 \%$ of all manure in the Netherlands:

Export of dry poultry manure to other EU-member states.

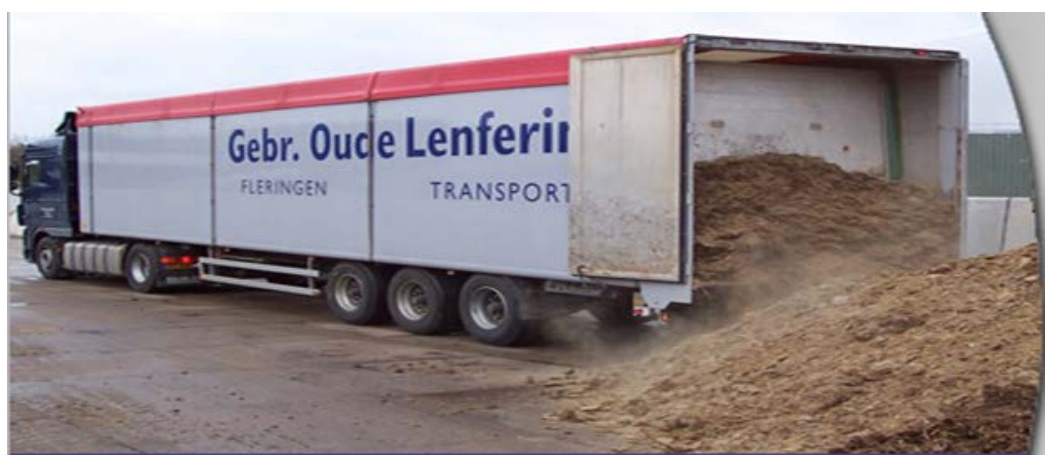

Figure 14 Transport of dry poultry manure with truck with walking floor

Ad 1): Obviously, the most common use of animal manure in the Netherlands is application as fertilizer on agricultural land. Manure application is only allowed when using low emission technology 
like manure injection on grassland and immediate covering with soil on arable land. The manure application period is limited to the early growing season of crops. By using animal manure as nutrient source for crops, more than $90 \%$ of synthetic phosphate fertilizers and more than $60 \%$ of synthetic nitrogen fertilizers have been replaced by phosphate and nitrogen from animal manure.

Ad 2): In 2014 the mandatory processing and export of surplus manure phosphate was introduced, resulting in an export of around 35 million kilograms of phosphate (around 3 million tons of solid manure) in 2015 (Source: Ministry of Economic Affairs, 2016). Concentrated manure products with little moisture and high nutrient levels, like dry poultry manure and solid fraction of pig manure, can be transported efficiently over longer distances. Cattle manure is preferred by arable farmers in the Netherlands because of its favourable characteristics, compared to pig and poultry manure ${ }^{13}$. Therefore the liquid cattle slurry with a high water content and lower nutrient levels is applied in the Netherlands as liquid fertilizer, whereas the pig and poultry manure is preferably exported.

Ad 3): The mineral concentrate (liquid NK-fertilizer) that is made by processing the liquid fraction of pig slurry with dissolved air flotation (DAF) and membrane filtration (reverse osmosis, RO) contains about $1 \%$ of ammonia nitrogen and about $1 \%$ of potash, and still $95 \%$ of water. It has a temporary exemption from the legal status of 'animal manure' and is considered equal to artificial fertilizer, so the nitrogen can be used on top of the maximum application rate for nitrogen from animal manure. Other end products are clean water and solid fraction.

In the Netherlands, this type of liquid NK-fertilizer is produced exclusively as response to the EU fertilizer legislation that allows only $170 \mathrm{~kg} / \mathrm{ha} / \mathrm{year}$ of nitrogen from animal manure (to be topped up with chemical nitrogen fertilizer, depending on crop uptake) and the wish of arable farmers to receive manure products with a low phosphate content (because of the strict phosphate application standards). Without specific legislation like this it will in most cases not be cost effective to produce this mineral concentrate, as compared to directly using raw slurry or liquid fraction from the first mechanical separation for land application. However, production of clean water drastically reduces the manure transport costs (see also section 5.4).

Ad 4): Started in the 1970's, veal calf slurry is treated in four centralized, regional installations (in total 800.000 tons per year). After mechanical separation, the liquid fraction is further processed by nitrification and denitrification, resulting mainly in $\mathrm{N}_{2}$ gas that is released into the atmosphere; some of the nitrogen, however, will be converted to nitric oxide $\left(\mathrm{N}_{2} \mathrm{O}\right)$ gas which is a potent greenhouse gas. The sedimented sludge is used as fertilizer on agricultural land. The liquid effluent, still rich in potash and other salts, is released into the sewer for further processing and discharge.

Ad 5): Since the introduction of the mandatory manure phosphate processing and export in 2014 (see Table 4), dry poultry manure and solid fractions from pig slurry separation are increasingly exported to other EU member states. Cattle manure (both slurry and solid) mostly stays in the Netherlands because of its lower phosphate contents and its higher nitrogen to phosphate ratio. In Table 5 the average characteristics of both slurry and solid manures are presented for the Netherlands.

\footnotetext{
13 Because of the strict phosphate application standards in the Netherlands, animal manure with a high nitrogen to phosphate ratio and a low phosphate content is preferred as fertilizer on agricultural land, so cattle manure is more suitable as fertilizer in the Netherlands than pig and poultry manure.
} 
Table 5 Average composition and nitrogen/phosphate ratio (N/P2O5) of cattle slurry, solid fraction of cattle slurry, solid cattle manure, fattening pig slurry, solid fraction of pig slurry and solid layer chicken manure in the Netherlands.

\begin{tabular}{|l|c|c|c|c|c|c|c|c|}
\hline & $\begin{array}{l}\text { Dry } \\
\text { matter } \\
(\mathrm{g} / \mathrm{kg})\end{array}$ & $\begin{array}{l}\text { Org. } \\
\mathrm{matter} \\
(\mathrm{g} / \mathrm{kg})\end{array}$ & $\begin{array}{l}\mathrm{N}- \\
\text { tot* } \\
(\mathrm{g} / \mathrm{kg} \\
)\end{array}$ & $\begin{array}{l}\mathrm{N}- \\
\mathrm{min} * \\
(\mathrm{~g} / \mathrm{kg})\end{array}$ & $\begin{array}{l}\mathrm{N} \text {-org* } \\
(\mathrm{g} / \mathrm{kg})\end{array}$ & $\begin{array}{l}\mathrm{P}_{2} \mathrm{O}_{5} * \\
(\mathrm{~g} / \mathrm{kg} \\
)\end{array}$ & $\begin{array}{l}\mathrm{K}_{2} \mathrm{O}^{*} \\
(\mathrm{~g} / \mathrm{kg} \\
)\end{array}$ & $\mathbf{N} / \mathbf{P}_{2} \mathbf{O}_{\mathbf{5}}$ \\
\hline Cattle slurry & 85 & 64 & 4.1 & 2.0 & 2.1 & 1.5 & 5.8 & $\mathbf{2 . 7}$ \\
\hline $\begin{array}{l}\text { Solid fraction of cattle } \\
\text { slurry }\end{array}$ & 250 & 188 & 7.8 & 1.6 & 6.2 & 4.4 & 5.8 & $\mathbf{1 . 8}$ \\
\hline Solid cattle manure & 194 & 152 & 5.3 & 0.9 & 4.4 & 2.8 & 6.1 & $\mathbf{1 . 9}$ \\
\hline Fattening pig slurry & 93 & 43 & 7.1 & 4.6 & 2.5 & 4.6 & 5.8 & $\mathbf{1 . 5}$ \\
\hline Solid fraction of pig slurry & 250 & 116 & 10.5 & 3.8 & 6.7 & 12.4 & 5.8 & $\mathbf{0 . 9}$ \\
\hline $\begin{array}{l}\text { Solid poultry manure } \\
\text { (layers) }\end{array}$ & 573 & 416 & 25.6 & 2.5 & 23.1 & 19.6 & 15.5 & $\mathbf{1 . 3}$ \\
\hline
\end{tabular}

*: $\mathrm{N}$-tot $=$ total nitrogen, $\mathrm{N}$ - $\min =$ ammonia nitrogen, $\mathrm{N}$-org $=$ organic nitrogen, $\mathrm{P}_{2} \mathrm{O}_{5}=$ phosphate, $\mathrm{K}_{2} \mathrm{O}=$ potash, $\mathrm{N} / \mathrm{P}_{2} \mathrm{O}_{5}=\mathrm{N}$-tot $/ \mathrm{P}_{2} \mathrm{O} 5$.

Because of the increasing amounts of phosphate that must be exported in the future, as expected, (see Table 4), it is foreseen that separation of pig slurry and digestate and export of solid fractions and poultry manure will increase during the coming years. 


\section{Manure Management Scenarios suitable for China}

\section{$5.1 \quad$ Introduction}

In the previous chapters an overview is given of the situation in China and the Netherlands with regard to animal husbandry, arable farming, manure management and legislation. Based on this information, in this chapter we distinguish possible manure management scenarios that could be considered for China in order to prevent negative environmental effects related to the production and use of manure. After evaluation of manure management technologies from the Netherlands and by assessing whether these technologies could be suitable for the Chinese situation, we now define three possible manure management scenarios. These scenarios are described in the following sections (5.2 5.4); in the last section (5.5) it is discussed what requirements need to be fulfilled for successful application of these scenarios in China.

\subsection{Scenario 1: Slurry application to grassland and arable farmland}

\subsubsection{Recycling nutrients}

When there is a local surplus of manure, due to the presence of large animal farms, manure is often regarded as a waste and an environmental risk. However, from an agronomic point of view, animal manure is a valuable fertilizer and a resource of nutrients. As the nutrient efficiency of the animals is only about $30 \%$, this means that about $70 \%$ of the nutrients from the feed end up in the manure. These nutrients include not only nitrogen $(N)$, phosphorus $(P)$, potassium $(K)$, magnesium $(\mathrm{Mg})$, calcium ( $\mathrm{Ca}$ ) and sulphur ( $\mathrm{S}$ ), but also trace elements like $\mathrm{Na}, \mathrm{Cl}, \mathrm{Cu}, \mathrm{Zn}, \mathrm{B}, \mathrm{Mn}, \mathrm{Fe}, \mathrm{Cr}, \mathrm{Mo}, \mathrm{Co}$, and $\mathrm{Se}$, all of which are important for plant and crop growth. Furthermore, animal manure contains organic matter that improves fertility and quality of the soil. Therefore a preferable manure management technology is to recycle the manure nutrients by bringing the manure back to productive grassland and arable land. That is the basis of scenario 1: application of the manure to grassland and arable farmland, with no or just some basic manure treatment technology involved. This also implies that the use of synthetic $\mathrm{N}$ and $\mathrm{P}$ fertilizer is replaced, or at least limited to a large extent. For a high crop production, the use of synthetic nitrogen fertilizer will remain necessary, in order to compensate nitrogen losses that occur during and after manure application to the field.

\subsubsection{No treatment and slurry application}

As discussed in the previous chapters, the focus in this project is on "liquid manure" or "slurry", which means that the water content is high, 90\% - 98\% (this implies that the nutrient concentration per ton of manure is relatively low ). This kind of slurry is mainly produced by pig and dairy farms. As the manure is a slurry, it needs to be transported by e.g. tanker trucks or pipe lines/irrigation channels. Application of this slurry to the fields (on grassland or at arable farms) means the slurry is transported to the farms "as it is" with no treatment. As the transport of slurry by tanker truck is relatively expensive compared to transport of more concentrated manures ${ }^{14}$ (e.g. solid manure), the application of the slurry to arable land should preferably take place as close to the animal farm as possible. The distance of manure transport that is considered as feasible depends on the local situation; in this scenario we assume a maximum of $100 \mathrm{~km}$ for slurry and $200 \mathrm{~km}$ for solid fractions. In the

\footnotetext{
${ }^{14}$ Per ton per kilometer the transport costs are comparable, but if only the concentrated manure (being a smaller amount) is transported instead of the slurry, total transportation costs are obviously lower.
} 
Netherlands and several other countries techniques have been developed for low-emission slurry application. These techniques involve manure incorporation and injection. As a result, the emission of both odour and ammonia is significantly reduced as compared to conventional splash-plate surface spreading of manure. Odour nuisance is significantly reduced and an ammonia emission reduction in the range of $50-90 \%$ is achieved in practice, depending on the technique used. This means that much more nitrogen is available for crop growth and the need for additional fertilization is significantly reduced. Slurry can be applied both on grassland and arable land,

When looking into China, we learned from Chapter 2 that, although recycling of manure to arable fields is believed by the central government as a right way to deal with the manure problem, there are not yet suitable technical means/machinery available to reuse and recycle the manure/slurry. Besides, some regulations forbid the direct discharge of manure (slurry) into the environment, which is often translated to "land application of untreated manure is not allowed". Thirdly, many arable farms in China were divided into very small pieces of land per household by the government to make sure every household can make a living by the land. These small farms are used to applying solid manure by hand and application of liquid manure cannot easily be achieved here. Although the policy now is changing into integrating the lands for the sake of intensive production and machinery operation, it will take some time to reach a radical change. Last but not least, arable farm slurry application is limited by the topography. For example, a lot of farms in Guangdong province are scattered all over the mountains and small hills, which makes it very hard to transport or apply the manure/slurry in large amounts.

To summarize, slurry application is worth to be promoted in China, but only when keeping in mind the preconditions listed below:

- availability and costs of transportation and labour,

- presence or absence of large arable farms' with suitable soil conditions (no rocks in top soil) and crops,

- availability of slurry application machines,

- availability of sufficient transport infrastructure and a suitable topography (no mountain ranges), willingness of arable farmers to use animal manure instead of artificial fertilizer and suitability of crops to receive slurry application,

- regulations or legislation that may (intentionally or not) either promote or discourage this development.

\subsubsection{Simple mechanical separation}

By mechanical separation, e.g. a screw press, the slurry is divided into a solid fraction (about $150 \mathrm{~kg}$ per ton of slurry) which contains $35-65 \%$ of all phosphorus and $20-30 \%$ of the nitrogen, and a liquid fraction (about $850 \mathrm{~kg}$ per ton of slurry) that contains the remaining phosphorus and nitrogen. (Other more advanced separators, such as a centrifuge or sieve belt press, might achieve higher removal efficiencies for $\mathrm{N}$ and $\mathrm{P}$, i.e. more of these compounds end up in the solid fraction.) The separation is usually done with an on farm separator.

In this scenario the liquid fraction is still applied to arable land close to the animal farm (if the above listed preconditions are met), but the solid fraction (with a relative large amount of the phosphorous) is transported relative far away from the farm. As the solid fraction, with a dry matter content of about $25-30 \%$, is a much more concentrated manure than the initial slurry, the total transportations costs are much lower than in the case all slurry is transported as the amount of concentrated manure is much smaller; therefore further transport distances are possible from an economical point of view. Solid fraction is preferably applied to arable land, e.g. vegetable farms.

Alternatively to direct application of the solid fraction to arable land, without further treatment, the solid fraction could be composted first. Composting (or "bio-thermal drying") is the aerobic process in which organic matter is oxidized by bacteria, resulting in the production of heat. Composting usually results in a higher dry matter content and in a reduction of pathogens and weed seeds. Techniques for composting range from "extensive composting" (windrow composting without or with limited processing like turning of the heap) to indoor "intensive composting" (tunnel composting) with forced aeration, regular turning, temperature control and off-gas cleaning (odour and ammonia removal). Scenario 1 is schematically shown in Figure 15, including the distribution of the total mass of the slurry and the main nutrients $(\mathrm{N}, \mathrm{P}, \mathrm{K})$. 


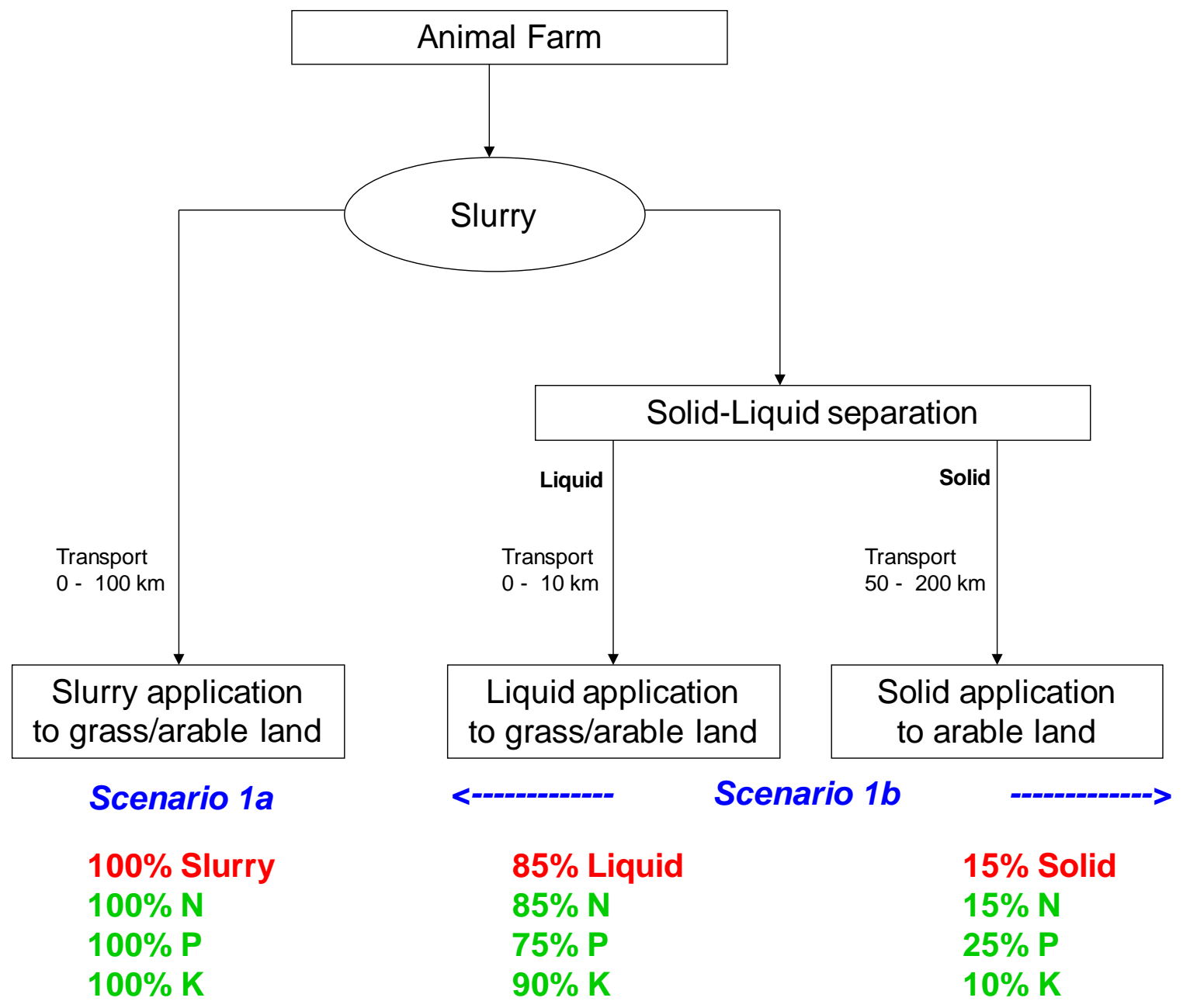

Figure 15 Schematic describing Scenario 1: Slurry application to grassland and arable land, with or without additional solid-liquid separation.

\subsection{Scenario 2: Biological waste water treatment system}

As described in scenario 1 , the basic idea of recycling nutrients is bringing back the nutrients to the arable land. In this way a balance is achieved between nutrient inputs and outputs, as long as sustainable application limits are used. However, this means that a large surface of arable land is required, either close to the animal farm or further away if (long distance) transport of the manure is applied.

An alternative scenario, when the surface of agricultural land is limited, is to apply the biological nitrification/denitrification process, a process in which nitrogen in the manure is (mainly) converted to harmless dinitrogen gas $\left(\mathrm{N}_{2}\right)$, which $80 \%$ of our atmosphere consists of. In this way the amount of nitrogen in the manure is drastically reduced. An unwanted side-effect is that also some nitrous oxide $\left(\mathrm{N}_{2} \mathrm{O}\right)$ is produced, which is a potent greenhouse gas. Although the nitrogen surplus is cut back in this way, the amount of phosphorus remains unchanged. The phosphorus is concentrated into a settled sludge. So the basis of scenario 2 is to reduce the nitrogen surplus by removing the nitrogen from the cycle of manure production followed by field application. The phosphorus in the sludge, however, still needs to be brought back to the fields.

In Figure 16, Scenario 2 is schematically shown, including the distribution of the total mass of the slurry and the main nutrients $(\mathrm{N}, \mathrm{P}, \mathrm{K})$. Figure 6 shows that the majority of $\mathrm{N}$ and $\mathrm{P}$ is removed from the slurry and after processing $90 \%$ of the initial slurry mass end up as "water". This water fraction could be discharged or be used for crop irrigation close to the animal farm. After the biological 
treatment, the produced water still contains some nitrogen ( $\mathrm{N}$-total $<200 \mathrm{mg} / \mathrm{litre}$ ) and, depending on the sludge removal/phosphorus removal technology used, 25 - $250 \mathrm{mg}$ P/litre, so crop irrigation is probably a much more sustainable option than discharge to surface water. Furthermore, the water contains a considerable amount of salts, such as potassium $(\mathrm{K})$, sodium $(\mathrm{Na})$, chloride $(\mathrm{Cl})$, as the concentration of these salts is the same as in the original slurry.

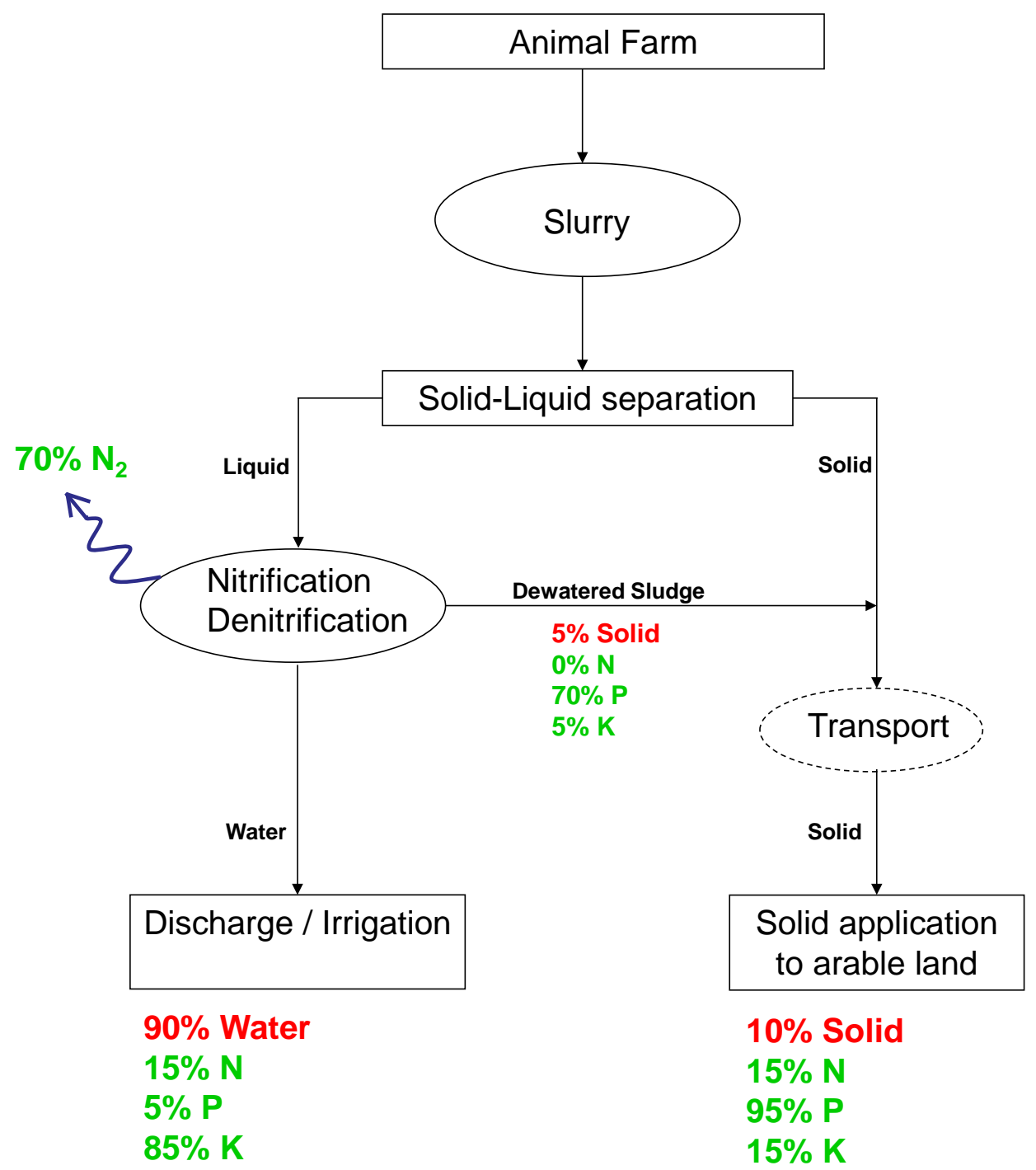

Figure 16 Schematic describing Scenario 2: Mechanical separation followed by biological treatment (nitrification/denitrification).

The produced sludge ( $20 \%$ of the initial liquid manure mass; dry matter content of about $4 \%$ ) can be further concentrated by dewatering techniques such as belt press, centrifuge etc. to a solid fraction containing $20-25 \%$ dry matter. In this way the volume of the sludge is reduced by $75 \%$. Together with solids from the first separation step, this eventually results in a solid fraction that is only $10 \%$ of the initial liquid manure mass. This solid fraction is much more concentrated than the original slurry, which makes it suitable for (long range) transport to other regions, followed by land application. Alternatively, the solid fraction could be composted prior to transport and land application (as also has been described under Scenario 1).

The technique of nitrification/denitrification can be considered as the 'standard' technique for treatment of municipal waste water treatment and is applied worldwide. Also for treatment of liquid animal manure this technique has been applied on full-scale for many years now. In the Netherlands several large installations of this type are used for treatment of veal calve manure, in Belgium and France these systems are mainly used for full-scale treatment of liquid pig manure. In China we visited a duck farm where a modified version of this technique was applied (see section 2.3.2). 


\subsection{Scenario 3: Advanced separation systems}

As discussed above, manure management technology should result in bringing the manure nutrients back to productive grassland and arable land. However, the liquid manure is very diluted and nutrient concentrations are low. This means that it is relatively expensive to transport this slurry with tanker trucks to regions where nutrients are needed for fertilization of grassland or arable land.

Most treatment systems for treating liquid animal manure start with a mechanical separation step, such as a screw-press or a decanting centrifuge. Also Scenario 1 and Scenario 2, as described above, start with this treatment step. The produced liquid fraction after these mechanical separation steps still contains a large amount of organic compounds, nitrogen, phosphorus and potassium (see Scenario $1 b$ to illustrate this). With additional advanced filtration steps, it is possible to further purify the liquid, resulting in clean water that does not contain any pollutant or nutrient anymore, this fraction can be discharged or applied for irrigation in vast amounts. This is the basis of scenario 3 : making clean water that can be discharged into the environment or applied for irrigation in vast amounts, close to the farm. All nutrients are accumulated in a concentrated brine and in the solid fraction. The 'concentrate' (with high nitrogen and potassium concentrations) could be transported at lower costs (as compared to transport of slurry, as the amount of concentrate is much smaller) to regions where nutrients are needed for fertilization of grassland or arable land. This concentrate might also be interesting to greenhouse growers in China, to replace part of the artificial fertilizer; it may not be suitable for vegetables and fruit that are not cooked prior to consumption due to the possible presence of pathogens. They may also be interested in the solid fraction to supply the plants/crops with organic matter.

A filtration technique that can produce such clean water is a reverse osmosis (RO) system. An RO systems contains membranes with such small pores (diameter: $1 \mathrm{~nm}$ ) that besides water $\left(\mathrm{H}_{2} \mathrm{O}\right)$ most other molecules and ions cannot pass the membrane. This results in a very clean water fraction that hardly contains any minerals. Transport of water through the membrane is achieved at high pressure (40 - 80 bar) that exceeds the osmotic pressure of the salts removed.

In order to prevent clogging of the membranes, pre-treatment of the liquid is necessary. The liquid from the first mechanical separation is further conditioned in a second step, for example dissolved air flotation (DAF) or ultrafiltration. Currently all RO systems in the Netherlands that treat manure use a sieve belt press for the first separation and DAF for the second separation, as ultrafiltration membrane technology was more expensive and less robust. Finally, the liquid after the DAF enters the RO membranes and a mineral concentrate (brine) and clean water is produced. The concentrate produced, a NK-fertilizer, is a liquid with an $\mathrm{N}$ concentration of $0.7 \%$, a $\mathrm{K}$ concentration of $0.7 \%$ and only a limited amount of $\mathrm{P}(0.01 \%)$.

Scenario 3 is schematically shown in Figure 17, including the distribution of the total mass of the slurry and the main nutrients $(N, P, K)$.

\section{Rationale}

As indicated in Figure 17, 50\% of the initial mass of the liquid manure is converted into clean water. This water can be discharged at low costs. All minerals are accumulated in the solid fraction and in the liquid concentrate, that add up to the remaining $50 \%$ of the initial mass. This means that still $50 \%$ of the initial mass needs to be transported to other regions, if no sufficient land is available around the animal farm, which can still be very costly. The main reason this advanced separation system is applied in the Netherlands is that the liquid NK-concentrate form the system is not regarded as animal manure in EU regulations but as artificial fertilizer. This means that arable farmers may use this concentrate to top up the allowed $170 \mathrm{~kg} \mathrm{ha/year}$ of nitrogen from animal manure to the crop needs, instead of using artificial fertilizer (see section 3.4.2). Because of the manure surplus situation in the Netherlands arable farmers receive a fee from the animal farmers for using this concentrate (as is also the case for untreated manure) - in a non-surplus situation the quality and composition of the concentrate might be a more important criterium. In this way the animal farmers have an extra opportunity to solve their nitrogen surplus. 


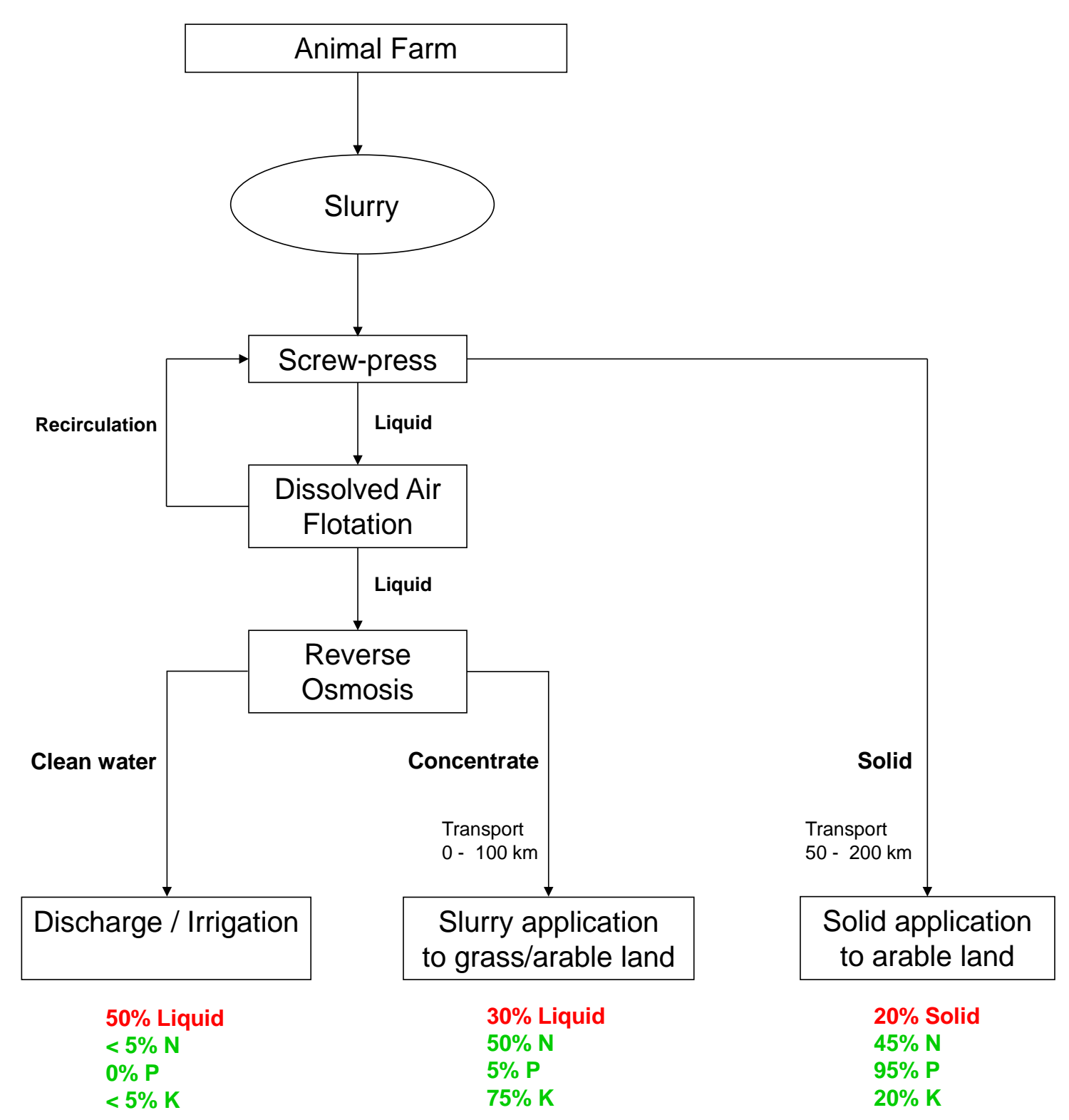

Figure 17 Schematic describing Scenario 3: Advanced separation with reverse osmosis. 


\section{Summary and Conclusion}

To recapitulate, Chapter 2 introduced the problems and manure policy system of China; Chapter 3 and 4 made a profile of Dutch manure policy and popular technologies. Based on the differences between the Netherlands and China on the one hand, and based on the similarities on the other hand, in Chapter 5 some concrete recommendations were given on manure technology and management scenarios. In chapter 6 , the findings of this paper are summarized.

\subsection{Requirements for adoption and implementation technologies in China}

In order to implement the scenarios described in chapter 5 in China, a thorough analysis is necessary of the requirements that need to be fulfilled for making it successful.

As already mentioned in the previous sections, a very important aspect is how adoption and implementation of these manure management scenarios is related to or embedded in national and local legislation. The driving force in the Netherlands for applying these technologies is the system of maximum application rates of $\mathrm{N}$ and $\mathrm{P}$ per hectare of grassland or arable land, that should lead to equilibrium fertilization. Therefore farmers and engineers were forced to develop technologies for manure treatment, which is the case for all scenarios that were described. Melse et al. (2017) ${ }^{15}$ give a calculation example of equilibrium fertilization for a Chinese dairy farm with manure treatment. It is necessary to embed manure application and treatment technologies into national and local legislation in China.

Secondly, an administrative system (database) has to be developed for the registration of animal numbers per farm, manure production per farm, transport movements (origin and destination) of manure per truck load, manure storages (owned or hired), nitrogen and phosphate quantities per truck load, surface of arable and vegetable farms. This system makes it possible to identify farms that do not comply with the regulations and to prevent environmental damage (dumping of manure, over fertilization, etc.). Administration, physical controls and enforcement are preferably done by a national or provincial competent authority under e.g. the Ministry of Agriculture or Environment.

Finally, an infrastructural system is necessary to transport and apply manure and manure products. As discussed under Scenario 1 (and it also applies to the concentrate from Scenario 3), this requires infrastructure for transport, storage and land application of liquid manure fertilizers. Furthermore, infrastructure is also needed for transport, storage and application of solid fertilizer fractions (all three scenarios). As part of the infrastructural system it is necessary to contract arable farmers, horticultural companies etc. to make sure that sufficient land is available for responsible application of manure, taking into account maximum application rates dependant on soil and crop needs.

\subsection{Regions to apply different recommended scenarios}

In chapters 2.5 the situation regarding manure production, crop production, availability of suitable farmland, climatological and topographical differences was discussed for several regions in China. By combining this information with the described scenarios in Chapter 6 , we are now able to conclude to what regions the manure management scenarios could be applied; this is summarized in Table 6.

\footnotetext{
${ }^{15}$ Melse, R.W.; Buisonjé, F.E. de; Qiao, W.; Dong, R. (2017). Manure nutrient application on a Chinese dairy farm with arable land: A case study based on Dutch experience of equilibrium fertilization. International J ournal of Agricultural and Biological Engineering 10 (4), p. 182-188.
} 
Table 6 Description of manure management scenarios and suitable regions for implementation.

\begin{tabular}{|c|c|c|}
\hline Scenarios & Key factors & Regions/ provinces \\
\hline $\begin{array}{l}\text { Scenario 1: } \\
\text { Slurry application to } \\
\text { grassland and arable } \\
\text { land (either with or } \\
\text { without additional } \\
\text { solid-liquid } \\
\text { separation) }\end{array}$ & $\begin{array}{l}\text { - Land application of untreated } \\
\text { slurry nearby farm (<100 km) } \\
\text { - If extended with separation: } \\
* \text { land application of liquid } \\
\text { fraction nearby farm }(<10 \\
\text { km) } \\
* \text { transport }(50-200 \mathrm{~km})+ \\
\text { land application of solid } \\
\text { fraction } \\
\text { - Costs: relatively cheap }\end{array}$ & $\begin{array}{l}\text { North/North-East of } \\
\text { China, the middle and } \\
\text { down streams of the } \\
\text { Yangtze River, Xinjiang: } \\
\text { Xinjiang, Heilongjiang, } \\
\text { Jilin, Liaoning, Hebei, } \\
\text { Henan, Shandong, Inner } \\
\text { Mongolia, Ningxi }\left({ }^{1}\right) ; \\
\text { Jiangsu, Anhui, } \\
\text { Zhejiang, Jiangxi, Hunan } \\
\text { and Hubei provinces }\left({ }^{2}\right)\end{array}$ \\
\hline $\begin{array}{l}\text { Scenario 2: } \\
\text { Mechanical separation } \\
\text { followed by biological } \\
\text { treatment of the } \\
\text { liquid fraction } \\
\text { (nitrification/ denitrifi } \\
\text { cation) }\end{array}$ & $\begin{array}{l}\text { - Volume reduction: } \\
\text { discharge/irrigation of liquid } \\
(90 \%) \\
\text { - Nitrogen }(\mathrm{N}) \text { has disappeared } \\
\text { - Transport }(50-200 \mathrm{~km})+ \\
\text { land application of solid } \\
\text { fraction ( } 10 \%) \\
\text { - Costs: moderate }\end{array}$ & $\begin{array}{l}\text { South-East of China, the } \\
\text { middle and down } \\
\text { streams of the Yangtze } \\
\text { River with paddy rice } \\
\text { dominance: } \\
\text { Jiangsu, , Anhui, } \\
\text { Zhejiang, Jiangxi, Hunan } \\
\text { and Hubei provinces }\left({ }^{2}\right) \text {; } \\
\text { Fujian, Guangdong, } \\
\text { Sichuan ( }{ }^{3} \text { ) } \\
\text { (in principle, this } \\
\text { scenario can also be } \\
\text { applied to the } \\
\text { North/North-East part of } \\
\text { China, but costs are } \\
\text { higher than for applying } \\
\text { proposed Scenario } 1 \text { for } \\
\text { that region) }\end{array}$ \\
\hline $\begin{array}{l}\text { Scenario 3: } \\
\text { Advanced separation } \\
\text { with reverse osmosis }\end{array}$ & $\begin{array}{l}\text { - Volume reduction: } \\
\text { discharge/irrigation of liquid } \\
(50 \%) \\
\text { - Transport (<100 km) + land } \\
\text { application of concentrate } \\
\text { (30\%) } \\
\text { - Transport of solid fraction } \\
(20 \%)(50-200 \mathrm{~km})+\text { land } \\
\text { application } \\
\text { - Costs: expensive }\end{array}$ & $\begin{array}{l}\text { South-East of China: } \\
\text { Fujian, Guangdong, } \\
\text { Sichuan }\left({ }^{3}\right) \\
\text { (In principle, this } \\
\text { scenario can also be } \\
\text { applied to the } \\
\text { North/North-East part of } \\
\text { China, but costs are } \\
\text { higher than for applying } \\
\text { proposed Scenario } 1 \text { for } \\
\text { that region) }\end{array}$ \\
\hline
\end{tabular}

$\left({ }^{1}\right)$ These provinces are indicated with a yellow colour in Figure 9; $\left({ }^{2}\right)$ these provinces are indicated with a green colour in figure $4 ;\left({ }^{3}\right)$ these provinces are indicated with a blue colour in Figure $9 ;\left({ }^{4}\right)$ Absolute values of costs are difficult to compare between the Netherlands. The main message is that the costs of the scenarios increase in the order of Scenario $1-->2-->3$.

Generally speaking, scenario 1 is normally the cheapest and preferred scenario. However, when this scenario cannot be implemented because of the specific regional situation (see chapter 5.2 for a list of preconditions), it may be necessary to use more advanced and thus more expensive technology. Then the technology of Scenario 2 comes to mind, as in this way the manure volume is drastically reduced and the nitrogen surplus is solved. If for some reasons Scenario 2 cannot be applied, or in case that additional benefits are associated with Scenario 3 (such as is the case in the Netherlands, where specific regulation are into force with regard to the concentrate from Scenario 3), then Scenario 3 could be chosen. Generally speaking, however, in a situation of large livestock farms and limited availability of large plots of grassland or arable land (such as is the case in Fujian and Guangdong), implementation of the cheaper Scenario 2 will be a more logical choice than to apply Scenario 3 in most cases, as the costs of Scenario 3 are significantly higher. 



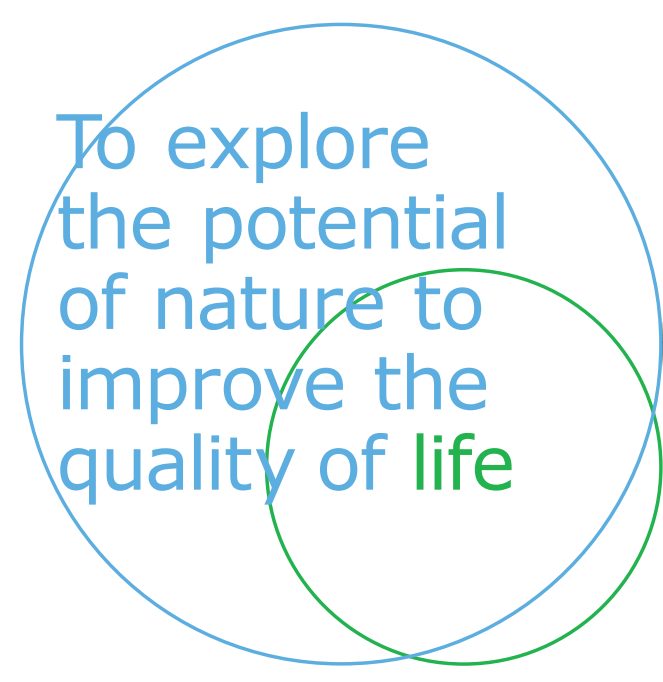

Wageningen Livestock Research P.O. Box 338

$6700 \mathrm{AH}$ Wageningen

The Netherlands

T +31 (0)317483953

E info.livestockresearch@wur.nl www.wur.nl/livestock-research

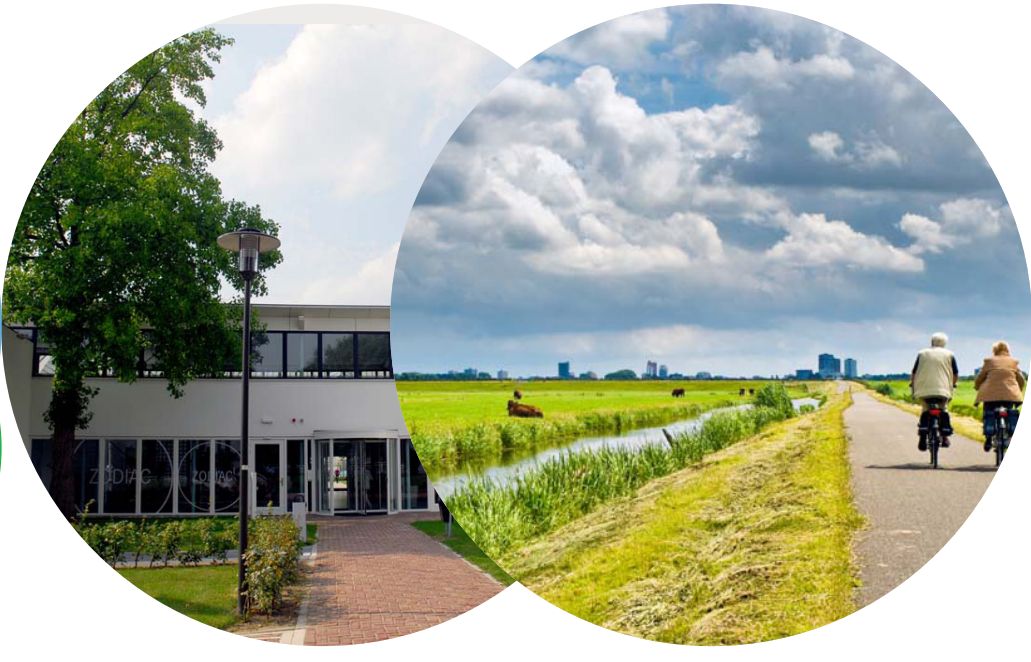

Wageningen Livestock Research creates science based solutions for a sustainable and profitable livestock sector. Together with our clients, we integrate scientific knowledge and practical experience to develop livestock concepts for future generations.

Wageningen Livestock Research is part of Wageningen University \& Research. Together we work on the mission: 'To explore the potential of nature to improve the quality of life'. A staff of 6,500 and 10,000 students from over 100 countries are working worldwide in the domain of healthy food and living environment for governments and the business community-at-large. The strength of Wageningen University \& Research lies in its ability to join the forces of specialised research institutes and the university. It also lies in the combined efforts of the various fields of natural and social sciences. This union of expertise leads to scientific breakthroughs that can quickly be put into practice and be incorporated into education. This is the Wageningen Approach. 